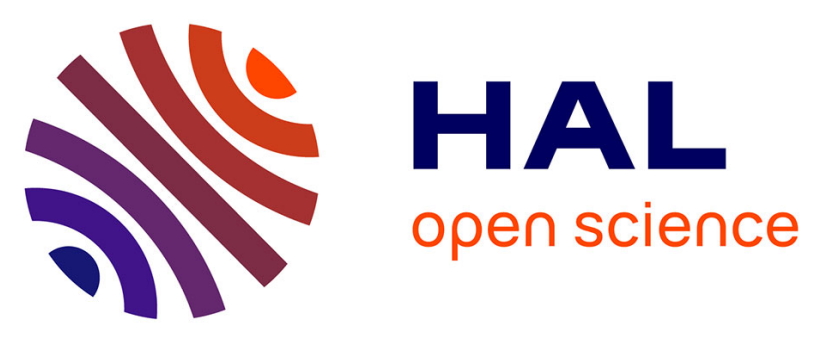

\title{
Element content and expression of genes of interest in guard cells are connected to spatiotemporal variations in stomatal conductance
}

Maxime Durand, David Cohen, Nathalie Aubry, Cyril Bure, Ivana Tomášková, Irène Hummel, Oliver Brendel, Didier Le Thiec

\section{To cite this version:}

Maxime Durand, David Cohen, Nathalie Aubry, Cyril Bure, Ivana Tomášková, et al.. Element content and expression of genes of interest in guard cells are connected to spatiotemporal variations in stomatal conductance. Plant, Cell and Environment, 2019, 10.1111/pce.13644 . hal-02352487

\section{HAL Id: hal-02352487 \\ https://hal.science/hal-02352487}

Submitted on 6 Nov 2019

HAL is a multi-disciplinary open access archive for the deposit and dissemination of scientific research documents, whether they are published or not. The documents may come from teaching and research institutions in France or abroad, or from public or private research centers.
L'archive ouverte pluridisciplinaire HAL, est destinée au dépôt et à la diffusion de documents scientifiques de niveau recherche, publiés ou non, émanant des établissements d'enseignement et de recherche français ou étrangers, des laboratoires publics ou privés.

\section{다(1)(2)}

Distributed under a Creative Commons Attribution - ShareAlikel 4.0 International 


\title{
Element content and expression of genes of interest in guard cells are connected to spatiotemporal variations in stomatal conductance
}

\author{
Maxime Durand $^{1}$ | David Cohen ${ }^{1}$ | Nathalie Aubry ${ }^{1}$ | Cyril Buré ${ }^{1}$ | Ivana Tomášková ${ }^{2}$ | \\ Irène Hummel ${ }^{1}$ | Oliver Brendel ${ }^{1}$ | Didier Le Thiec ${ }^{1}$ (D)
}

${ }^{1}$ Inra, Université de Lorraine, AgroParisTech, SILVA, F-54280 Champenoux, France

${ }^{2}$ Department of Genetics and Physiology of Forest Trees, Faculty of Forestry and Wood Sciences, Czech University of Life Sciences Prague, Prague 165 00, Czech Republic

\section{Correspondence}

D. Le Thiec, Inra, Université de Lorraine, AgroParisTech, SILVA, F-54280 Champenoux, France.

Email: didier.lethiec@inra.fr

Funding information

FP7 Food, Agriculture and Fisheries, Biotechnology, Grant/Award Number: Watbio / 311929; Institut National de la Recherche Agronomique, Grant/Award Number: Dpt EFPA; Lorraine region; French National Research Agency, Grant/Award Number: ANR12-LABXARBRE-01; European Union's Seventh Programme, Grant/Award Number: 311929

\begin{abstract}
Element content and expression of genes of interest on single cell types, such as stomata, provide valuable insights into their specific physiology, improving our understanding of leaf gas exchange regulation. We investigated how far differences in stomatal conductance $\left(g_{s}\right)$ can be ascribed to changes in guard cells functioning in amphistomateous leaves. $g_{\mathrm{s}}$ was measured during the day on both leaf sides, on well-watered and drought-stressed trees (two Populus euramericana Moench and two Populus nigra L. genotypes). In parallel, guard cells were dissected for element content and gene expressions analyses. Both were strongly arranged according to genotype, and drought had the lowest impact overall. Normalizing the data by genotype highlighted a structure on the basis of leaf sides and time of day both for element content and gene expression. Guard cells magnesium, phosphorus, and chlorine were the most abundant on the abaxial side in the morning, where $g_{s}$ was at the highest. In contrast, genes encoding $\mathrm{H}^{+}$-ATPase and aquaporins were usually more abundant in the afternoon, whereas genes encoding $\mathrm{Ca}^{2+}$-vacuolar antiporters, $\mathrm{K}^{+}$ channels, and ABA-related genes were in general more abundant on the adaxial side. Our work highlights the unique physiology of each leaf side and their analogous rhythmicity through the day.
\end{abstract}

\section{KEYWORDS}

abaxial and adaxial surfaces, droughts, elements, gene expression, plant stomata, Populus, stomatal conductance

\section{1 | INTRODUCTION}

Stomata are small pores on the surface of the leaf responsible for almost all gas exchange between the leaf internal environment and the surrounding air. They are composed of two guard cells that modify their volume, adjusting the central aperture and controlling the flow of gases in and out of the leaf. These adjustments are regulated by a variety of internal and external factors, including but not limited to water availability (Monclus et al., 2006), irradiance (Shimazaki, Doi, Assmann,
\& Kinoshita, 2007), and circadian rhythms (de Dios, 2017). Regulation of stomatal aperture is considered a key phenomenon, maximizing $\mathrm{CO}_{2}$ uptake for photosynthesis with regard to water loss by transpiration (Cowan \& Farquhar, 1977), whose importance increases as internal and environmental conditions become more limiting.

Poplars are dicots, model trees for molecular studies (Jansson \& Douglas, 2007; Tuskan et al., 2006), with amphistomateous leaves. As such, despite being in the same environment, each leaf side experiences a different magnitude of irradiance and temperature (Clum, 
1926; Sheriff, 1979). Literature evidence suggests that guard cell sensitivity to irradiance (Kassam, 1973), vapour-pressure deficit (Pallardy \& Kozlowski, 1979), leaf water potential (Kanemasu \& Tanner, 1969), and ozone (Dumont et al., 2014) differs between leaf sides. Moreover, some species showed independent stomatal regulation between surfaces (Mott, 2007; Richardson, Brodribb, \& Jordan, 2017), consistent with an optimal stomatal behaviour of each leaf side. This suggests that, in poplars, stomatal movements under drought and along the day may depend on the side of the leaf.

As a consequence of global climate change, droughts are expected to be more intense and frequent in the future (Dai, 2012; Intergovernmental Panel on Climate Change, 2014). A prolonged reduction in water availability will induce a wide variety of severe and long-lasting humanitarian, economic, and environmental impacts on ecosystems and societies (Touma, Ashfaq, Nayak, Kao, \& Diffenbaugh, 2015). Among them, the impact of drought on forests is a central concern in global climate change research given the interrelation between forests and climate (Bonan, 2008). Poplars are commonly distributed along riparian ecosystems due to their high water requirements (Tschaplinski \& Blake, 1989). Their cultivation however usually extend to mesophyte habitats where they are more frequently subjected to soil water deficit. Plant response to drought is complex, but stomatal closure and a reduction in plant productivity is generally observed (Ciais et al., 2005; Coopman et al., 2008; Monclus et al., 2006).

For soil water deficit and high vapor pressure deficit (VPD) conditions, it remains unresolved whether hydraulic or hormonal mechanisms are responsible for stomatal closure (Merilo et al., 2018; Rodriguez-Dominguez et al., 2016). One hypothesis states that a decrease in stomatal conductance $\left(g_{\mathrm{s}}\right)$ during drought is mostly driven by hormonal signals such as abscisic acid (ABA), which are generated independently of leaf water status (Davies \& Zhang, 1991; Dodd, 2005; Tardieu \& Simonneau, 1998). However, the complex regulation of stomatal functioning can involve a number of actors, from phytohormones to strigolactones (Acharya \& Assmann, 2009; Lv et al., 2018). It has alternatively been proposed that stomatal closure during edaphic droughts is caused by an actively mediated negative feedback response of stomata to reduced leaf turgor (Brodribb \& Cochard, 2009; Buckley, 2005; Sperry, Hacke, Oren, \& Comstock, 2002). ABA is a central plant hormone responsible for promoting stomatal closure and inhibiting opening under drought (Chaves, Maroco, \& Pereira, 2003; Huang, Wu, Abrams, \& Cutler, 2008). In recent years, evidence has accumulated showing that guard cells possess the full ABA biosynthesis pathway (Bauer et al., 2013) and the early ABA signal transduction (Zhang et al., 2015). ABA binds and inhibits PP2C-type phosphatases by binding to the PYR/PYLs family of proteins (Merilo et al., 2013), including ABI1 (Park et al., 2009; Yoshida et al., 2006). This in turns relieves the repression on OST1, which inactivates the KAT1 inward-rectifying potassium channel (Sato et al., 2009) and activates the S-type anion channel SLAC1 (Geiger et al., 2009). These channels, among others, induce a reduction of osmotic potential inside the guard cells leading to a flow of water outward, which results in stomatal closure (Schroeder \& Hedrich, 1989; Schroeder, Raschke, \& Neher, 1987).
In addition, circadian rhythms in transcript accumulation (Wilkins, Waldron, Nahal, Provart, \& Campbell, 2009) and gas exchange (de Dios, 2017) are limiting our ability to fully understand the molecular signals involved in stomatal movements. A number of genes involved in the regulation of stomatal movements were found to be gated by the circadian clock, including ABA biosynthesis and signalling pathways (for a complete review, see Seung, Risopatron, Jones, \& Marc, 2012) and TIPs and PIPs (aquaporins) mRNA levels (Chaumont \& Tyerman, 2014). Circadian rhythms appear to be cell-specific as stomata were shown to have a distinct rhythmicity compared with surrounding mesophyll cells in Arabidopsis thaliana (Hassidim et al., 2017; Yakir et al., 2011). Given the importance of stomata in regulating gas exchange and thus the productivity of plantations, there is a need to better understand the regulation of $g_{s}$ during the day and under different water availabilities.

Specifically studying stomata independently from the surrounding mesophyll cells is not trivial (Leonhardt et al., 2004). Hence, not much is known about the physiological and molecular processes in guard cells driving stomatal conductance in trees species such as poplars. To increase our understanding of the differences in such cellular processes among genotypes, between leaf sides, during the day and plastic responses related to soil water deficit, there is a need for studies targeting a specific cell type.

To test well-established processes exerted by the guard cells, quantification of their element content and their expression of 27 genes of interest were monitored separately on both leaf sides from leaves harvested in the morning and the afternoon. We used two Populus nigra $\times$ Populus deltoides (Populus euramericana, Moench) and two P. nigra (L.) genotypes grown in parallel under control and soil water deficit conditions. Given this experimental set-up, we aimed to answer the following questions: (a) Is there a constitutive difference among genotypes of element content and gene expression in poplar guard cells? (b) Do factors such as water regime, time of the day, and leaf side induce a plastic response in terms of guard cells (i) element content and (ii) gene expression?

\section{I MATERIAL AND METHOD}

\section{1 | Plant material and growth conditions}

Woody cuttings of four poplar genotypes belonging to different species or commercial hybrids (Carpaccio and I214: $P$. deltoides $\times$ P. nigra, Moench, 6J29 and N38: P. nigra, L.) were grown in a fully automated glasshouse under natural light with a free range for air temperature between $15^{\circ} \mathrm{C}$ and $25^{\circ} \mathrm{C}$ at INRA-Grand-Est $\left(48^{\circ} 45^{\prime} 09.3^{\prime \prime} \mathrm{N}, 6^{\circ} 20^{\prime}\right.$ $27.6^{\prime \prime} \mathrm{E}$; Champenoux, France), as described previously (Durand, Brendel, Buré, \& Le Thiec, 2019). Genotypes were chosen based on their contrasting drought response: 1214 and $6 \mathrm{~J} 29$ are generally found to be sensitive to drought (Chen, Wang, Altman, \& Huttermann, 1997; Giovannelli et al., 2007; Muller \& Lambs, 2009; Viger et al., 2016). Sixteen cuttings per genotype were planted in $9.5 \mathrm{~kg}( \pm 1.5 \%)$ of a sand/peat mixture $(1 / 1, \mathrm{v} / \mathrm{v})$, complemented with fertilizer $\left(1 \mathrm{~g} \mathrm{~L}^{-1}\right.$ of 
CaMg $\left(\mathrm{CO}_{3}\right)_{2}$ and $20 \mathrm{~g}$ of Nutricote T100, 13:13:13 NPK and micronutrients, FERTIL S.A.S., Boulogne-Billancourt, France). Each 10$\mathrm{L}$ pot was covered with $1.4 \mathrm{~kg}$ of white marble gravel (8-12 mm). Pots were weighed and watered to $27.9 \%$ volumetric soil water content (SWC; $85 \%$ of field capacity) at least three times a day with a robot (Durand et al., 2019). After 60 days of precultivation, watering was stopped for half the individuals (randomly chosen) until an SWC of $18.3 \%$ was reached. This controlled soil water deficit was maintained constant for 25 days using a pot-specific linear regression between SWC measured by time domain reflectometry (HD2, IMKO, Ettlingen, Germany) and pot mass ( $R^{2}>$.8). Reference masses were adjusted each week to take the plant growth into account. Growth, transpiration, and meteorological data are available in Durand et al. (2019).

\subsection{Leaf gas exchange and leaf sampling}

Leaf gas exchange and leaf sampling were performed sequentially in order to accurately capture stomatal conductance at the time of sampling. The first fully expanded leaf (selected before the drought) and the one immediately below were sampled 21 days after the start of the drought experiment at 10:30 a.m. and 3:00 p.m. local time, respectively. At the time, the natural daytime lasted $16 \mathrm{hr}$ (starting at 4:30), global radiation was $297.2 \pm 47.8$ and $145.6 \pm 45.1 \mathrm{~W} \mathrm{~m}^{-2}$, air temperature was $24.9 \pm 0.2$ and $24.8 \pm 0.2^{\circ} \mathrm{C}$, and vapour-pressure deficit was $1.31 \pm 0.02$ and $1.20 \pm 0.07 \mathrm{kPa}$ for the two sampling events, respectively. From previous $g_{s}$ time-course measurements, stomata were likely fully open in the morning and in a closing phase in the afternoon (Durand et al., 2019). The last watering event was completed $2 \mathrm{hr}$ before each sampling. A leaf porometer was used in order to measure $g_{s}$ separately on the abaxial and adaxial surfaces of the leaves (SC-1 porometer; Decagon Devices, Inc., Pullman, WA, USA). Stomata being on the leaf surfaces, sampled leaves were flash frozen in liquid nitrogen immediately after measurements, to guarantee both RNA integrity and that diffusive elements remained in guard cells (Amsellem et al., 1983; Jaiprakash et al., 2003).

\section{3 | X-ray microanalysis}

Sample preparation and microanalyses were performed following Dumont et al. (2014), except for the use of a tungsten coating on the samples and a probe intensity of $1 \mathrm{nA}$, in order to allow analyses in stomata specifically. Although the analysed X-rays originate from a lower layer in the sample than electrons (Amsellem et al., 1983), the electron beam diameter and depth of penetration is lower than 2 $\mu \mathrm{m}$ and has been simulated in a Monte Carlo procedure (Pouchou \& Pichoir, 1991); 20 guard cells, each belonging to different stomata of freeze-dried leaves, were specifically targeted and analysed for each of the two leaf sides, the two times of day, the two water treatments, and the four genotypes with six replicates in each condition. Microanalyses were corrected by measuring the content of beech leaves powder of known mass fraction (CRM 100, BCR ${ }^{\circledR}$ certified reference material, Commission of the European Communities, Brussels,
Belgium) for sodium ( $\mathrm{Na}$ ), magnesium $(\mathrm{Mg})$, phosphorus $(\mathrm{P})$, chlorine $(\mathrm{Cl})$, potassium $(\mathrm{K})$, and calcium $(\mathrm{Ca})$. All forms were measured, both organic and inorganic. We also computed a ratio of anions over cations for each guard cell (i.e., $\mathrm{P}$ and $\mathrm{Cl}$ over $\mathrm{Na}, \mathrm{Mg}, \mathrm{K}$, and $\mathrm{Ca}$ later referred to as $A n / C a t)$. Values were converted from percent to "per mille" (or $\mathrm{mg} \mathrm{g}^{-1}$ ) of dry mass.

\section{4 | Guard cell microdissection, RNA extraction and cDNA amplification}

Guard cells microdissection, RNA isolation, RNA reverse-transcription, and cDNA amplification were performed following Dumont et al. (2014). A brief description of the methods is given hereinafter. If not otherwise specified, protocols were performed following the manufacturer's instructions; 1,000 stomata per sample were microdissected using the PALM MicroBeam system (Carl Zeiss Microlmaging GmbH, Jena, Germany). Total RNA was extracted using Qiagen RNeasy Plus Micro Kit (Qiagen, Courtaboeuf, France). Previous tests in our lab and in the literature show that the process of freeze-drying and preparing microscopic slide does not impact the RNA integrity (Damsteegt, McHugh, \& Lokman, 2016; Dumont et al., 2014; GarcíaBaldenegro et al., 2015; Heinen et al., 2014; Jaiprakash et al., 2003). Transplex ${ }^{\circledR}$ Whole Transcriptome Amplification Kit (MERCK, SaintQuentin Fallavier, France) was used for RNA reverse transcription and cDNA amplification (100 $\mu$ l twice by sample). The latter was purified by Gene Elute PCR (SIGMA, Saint-Quentin Fallavier, France). cDNA purity and concentration were measured (Nanodrop 1000; Thermo Scientific, Illkirch, France). All cDNA samples exhibited a good purity level $\left(1.6<A_{260} / A_{280}<2.0\right.$ and $\left.1.3<A_{260} / A_{230}<1.9\right)$, and each sample was diluted to get $2.5 \mathrm{ng} \mu^{-1}$. Absence of genomic DNA was confirmed by PCR with intron-flanking primers.

\section{5 | Expression of genes of interest and real-time PCR}

The genes of interest were retrieved on the Populus genome v3.0 (Phytozome, RRID:SCR_006507, https://phytozome.jgi.doe.gov/pz/ portal.html; Tuskan et al., 2006). The genes of interest were selected for their putative role in encoding ionic pumps, aquaporins, transporters involved in stomatal movements, and phototropins, $\beta$-carbonic anhydrases, and genes linked to ABA biosynthesis and signalling. Genes were selected in regard to previous studies (Cohen et al., 2010; Dumont et al., 2014; Heinen et al., 2014) on the basis of a high expression level in poplar guard cells (when available, and in leaves otherwise), their differential expression among genotypes, between leaf sides, water availability, and time of day. The design of primers, with adequate specificity for all four genotypes, was also a limiting step for gene selection. Only primers with a reduced risk of primer dimer formation or nonspecific amplification were selected. Because the expression of gene of interest approach is not exhaustive by definition, we chose to investigate genes with different roles, instead of a whole family of genes. Thus, our interpretation is not limited to a 
single family of transporters but benefits from a more exhaustive assessment of guard cell processes linked with stomatal regulation. The targeted genes and their description are provided in Table 1 (additional information is given in Table S1).

Real-time PCR was performed in a 96-well Mx3005P thermocycler (Agilent, Waghaeusel-Wiesental, Germany) using the recommended cycling programme: $5 \mathrm{~min}$ at $95^{\circ} \mathrm{C}, 40$ cycles of $5 \mathrm{~s}$ at $95^{\circ} \mathrm{C}$, and 20 $\mathrm{s}$ at $58^{\circ} \mathrm{C}$ or $60^{\circ} \mathrm{C}$ depending on primers, followed by melting cycle to ensure a single amplicon (Dumont et al., 2014). The mix contained $10 \mathrm{ng}$ of cDNA, the reference dye (ROX, Agilent technologies), genespecific primers, and the Brilliant III UltraFast SYBR GREEN qPCR Master Mix (Agilent, Santa Clara, CA). No-template control reactions were prepared for each gene. The plate set-up included all samples from two genotypes and the negative controls. The $\mathrm{Ct}$ values were determined with the same threshold. For each targeted genegenotype group, efficiency was calculated from standard curves over seven dilutions. Efficiencies varied from $65 \%$ to $102 \%\left(R^{2} \geq .985\right)$ and were taken into account in all subsequent calculations (Bizet et al., 2015). Among the studied genes, UBQ11 (Brunner, Yakovlev, \& Strauss, 2004), QUAC1 (Dumont et al., 2014), and BAM1 were the most stable and used as references, together with an external control (GENORM v3.5, RRID:SCR_006763, https://genorm.cmgg.be/; Mestdagh et al., 2009; Vandesompele et al., 2002). The fluorescent threshold being set constant, the nonnormalized expression level was computed as $R Q=1 /\left(\mathrm{Ta} \cdot \mathrm{E}^{\mathrm{Ct}}\right)$, Ta being the amplicon length in bp and E the efficiency (Bizet et al., 2015; Gutierrez et al., 2008).

TABLE 1 Description of the genes studied and their localization

\begin{tabular}{|c|c|}
\hline Genes & Description \\
\hline NCED3.1 & Key enzyme in ABA biosynthesis (9-cis-epoxycarotenoid dioxygenase). \\
\hline NCED3.2 & Key enzyme in ABA biosynthesis (9-cis-epoxycarotenoid dioxygenase). \\
\hline$A B I 1$ & Protein phosphatases type 2C (PP2Cs), negative regulator of ABA promotion of stomatal closure. \\
\hline OST1 & $\begin{array}{l}\text { SNF1-related protein kinase, involved in ABA-induced stomatal closure by activating of S-type anion channels and } \\
\text { inhibiting inward rectifying potassium channel. }\end{array}$ \\
\hline PYL2 & $\begin{array}{l}\text { PYR/PYL/RCAR family of protein, inhibits the activity of group-A protein phosphatases type } 2 \mathrm{C} \text { (PP2Cs) when } \\
\text { activated by ABA. }\end{array}$ \\
\hline PYL4 & $\begin{array}{l}\text { PYR/PYL/RCAR family of protein, inhibits the activity of group-A protein phosphatases type } 2 C \text { (PP2Cs) when } \\
\text { activated by ABA. }\end{array}$ \\
\hline PYL8 & $\begin{array}{l}\text { PYR/PYL/RCAR family of protein, inhibits the activity of group-A protein phosphatases type } 2 \mathrm{C} \text { (PP2Cs) when } \\
\text { activated by ABA. }\end{array}$ \\
\hline CA1 & Beta-carbonic anhydrase, involved in $\mathrm{CO}_{2}$-mediated stomatal closure (chloroplast). \\
\hline CA4 & Beta-carbonic anhydrase, involved in $\mathrm{CO}_{2}$-mediated stomatal closure (PM). \\
\hline PHOT1 & Blue light photoreceptors, mediate blue light-dependent activation of the plasma membrane $\mathrm{H}^{+}$-ATPases \\
\hline PHOT2 & Blue light photoreceptors, mediate blue light-dependent activation of the plasma membrane $\mathrm{H}^{+}$-ATPases \\
\hline AKT2 & Inward rectifying potassium channel (PM), responsible for the $\mathrm{Ca}^{2+}$ sensitivity of the $\mathrm{K}^{+}$uptake channel. \\
\hline KAT1.2 & Inward rectifying potassium channel (PM), responsible for the $\mathrm{Ca}^{2+}$ sensitivity of the $\mathrm{K}^{+}$uptake channel. \\
\hline KAT3 & $\begin{array}{l}\text { Inward rectifying potassium channel (PM), responsible for the } \mathrm{Ca}^{2+} \text { sensitivity of the } \mathrm{K}^{+} \text {uptake channel. Involved in } \\
\text { down-regulating AKT1 and KAT1 channel activity by forming heteromers. }\end{array}$ \\
\hline OST2 & Proton ATPases (PM) \\
\hline AHA11 & Proton ATPases (PM) \\
\hline SLAC1 & $\begin{array}{l}\text { Slow anion channel (PM), involved in stomatal closure in response to a variety of signals including elevated } \mathrm{CO}_{2} \text {, ozone, } \\
\text { ABA, darkness, and humidity. }\end{array}$ \\
\hline CAX1 & Calcium antiporter (V) \\
\hline CAX1.6 & Calcium antiporter (V) \\
\hline NHX1.13 & Potassium, sodium/proton antiporter $(\mathrm{V})$ involved in salt tolerance and ion homeostasis \\
\hline PIP1.2 & Aquaporin: plasma membrane intrinsic protein (PM) \\
\hline PIP2.1 & Aquaporin: plasma membrane intrinsic protein (PM) \\
\hline PIP2.5 & Aquaporin: plasma membrane intrinsic protein (PM) \\
\hline TIP1.3 & Aquaporin: tonoplast intrinsic protein (V) \\
\hline TIP1.4 & Aquaporin: tonoplast intrinsic protein (V) \\
\hline TIP2.1 & Aquaporin: tonoplast intrinsic protein (V) \\
\hline TIP2.2 & Aquaporin: tonoplast intrinsic protein (V) \\
\hline
\end{tabular}

${ }^{a}$ Abbreviations: PM, plasma membrane; V: vacuole. 
The normalized expression of targeted genes were computed by dividing their RQ by the geometric average of the reference gene's RQ (Bizet et al., 2015).

\section{6 | Statistics}

Statistics were performed using R 3.5.1 (R Project for Statistical Computing, RRID:SCR_001905, https://cran.r-project.org/, all data used are available in Table S2). We used a type 2 factorial analysis of variance design to study the variation of $g_{s}(n=6)$, element content $(n=$ $6)$, and normalized mRNA levels $(n=4)$ by genotype, water regime, time of day, and leaf side and their first-order interaction. Given the complexity of the design, we decided to focus our interpretation of the dataset on the significant main factors and their first-order interactions, instead of computing all pairwise comparisons between our 32 groups. This enabled us to explore the major trends with a larger sample size and a higher statistical power than if we specifically addressed each pairwise comparison. Normalized transcript levels were transformed with a logarithmic function of base 2 in order to achieve a normal distribution of the data. Post hoc contrast analyses were performed to test differences between specific modalities of the studied factors depending their significance, and $P$ values were adjusted to control for the false discovery rate. The partial $R^{2}$ was calculated to compare the contribution with the explained variable of each of the four dependent variables. We performed a principal component analysis (PCA) on the six elements studied and the ratio An/Cat on one hand and on the expression data of 27 genes of interest on the other hand. We fitted to every variable a linear model that included the highly significant genotype effect as a dependent factor. The residuals of these models were used as the data for the two PCA in order to emphasize the other main effects (water regime, time of day, and leaf side). Stomatal conductance data were fitted with a similar model, and the residuals were added as a supplementary variable.

\section{3 | RESULTS}

\section{1 | Stomatal conductance}

Testing for genotypic, water availability, time of day, and leaf side effects on $g_{s}$ measured immediately before sampling the leaves, we found all four to be significant (Table 2, $P<.002$ in all cases). Drought-stressed poplars had an overall $20 \%$ lower $g_{s}$ than wellwatered trees. Because there was no interaction with the water treatment, we showed the average $g_{s}$ of both treatments (Figure 1). The significant interaction between genotype and time of day $(P=.023)$ showed that the afternoon decrease of $g_{s}$ tended to be stronger in both hybrid poplars than in the black poplars (Figure 1). Black poplars exhibited in general a higher $g_{s}$ than the hybrid poplars, and $g_{s}$ was overall higher on the abaxial side. Essentially, the highest $g_{s}$ tended to be observed on the abaxial side, in the morning and on wellwatered trees for all genotypes, whereas the adaxial side, in the afternoon on drought-stressed trees, showed the lowest $g_{s}$.

\subsection{Genotypic diversity of element content and gene expression within guard cells}

In this study, element content was measured as the whole guard cell average. We found significant genotypic diversity in all measured elements (Figure S1, Table 2, in all cases $P<.001$ ). The genotype effect was always the factor explaining the total variance of element content the most (Table S3). To highlight these genotypic differences, we decided to show the genotype means for each element in Figure 2. Partial $R^{2}$ for genotype ranged from.16 for the $\mathrm{P}$ content to.7 for the $\mathrm{Cl}$ content (Na: .57, Mg: .49, P: .16, Cl: .70, K: 0.33, Ca: 0.21). The main elements in the guard cells were $\mathrm{K}$ and $\mathrm{Ca}$. $\mathrm{Na}$ content was the highest in the guard cells of the hybrid poplars, and especially in Carpaccio were it was 3.1, 5.3, and 3.8 times higher than 1214, 6J29, and N38 respectively. Additionally, $\mathrm{Mg}$ content was 1.7 times higher in Carpaccio than in the other three genotypes, but $\mathrm{K}$ content was 1.6 times higher in 1214 than in the other three genotypes. On the other hand, $\mathrm{Cl}$ content was 4.6 times lower in both hybrid poplars than in the two black poplar genotypes. This effect was passed on in our calculation of An/Cat, which was 2.2 times lower in the two hybrid poplars than in the $P$. nigra genotypes. Moreover the guard cells of $6 \mathrm{~J} 29$ showed a $\mathrm{P}$ and $\mathrm{Ca}$ content, respectively, $17 \%$ and $24 \%$ lower than in the other three genotypes on average.

The expression of genes of interest in the guard cells was also structured according to genotype. Figures 3 and S2 show the backtransformed mean of normalized mRNA levels by genotype, that is, by applying a base 2 exponential to the means of the log2transformed data, to be consistent with statistical analyses. For all measured transcripts (in all cases $P<.001)$ except for CAX1 $(P=.34)$, the genotype effect was always the factor explaining the total variance of normalized mRNA levels the most (Table S3). Partial $R^{2}$ for the genotype effect ranged from 0.13 to 0.98 for AKT2 encoding a $\mathrm{K}^{+}$channel and PYL2, encoding an ABA receptor, respectively, with an average of 0.57. Overall, the normalized expression of NCEDs, encoding 9-cis-epoxycarotenoid dioxygenases involved in ABA biosynthesis, were the highest in black poplars. Specifically, N38 and 6J29 exhibited the highest accumulation of transcripts for NCED3.1 and NCED3.2, respectively (Figure S2a,b). Conversely, ABA signalling pathway-related transcripts appeared more expressed in I214 guard cells, and especially the genes encoding the ABA receptor PYL2 and PYL8 (Figure S2e,g). Carpaccio was consistently among the genotypes with the lowest accumulation of transcripts related to both ABA biosynthesis and signalling pathways. Regarding ß-carbonic anhydrases, N38 exhibited equivalent levels of CA1 and CA4 mRNA, whereas for the other genotypes, CA1 transcripts were accumulated up to 100 times more than CA4. Hence, CA1 normalized transcript levels were the highest in the guard cells of Carpaccio and 6J29, but CA4 levels were the highest in the guard cells of N38 (Figure S2h,i). The transcript accumulation of genes encoding phototropins PHOT1 and PHOT2 were significantly different across all genotypes. Concerning ion channels, I214 was often the genotype with the lowest level of transcripts for inward-rectifying $\mathrm{K}^{+}$channels (AKT2 and KAT3) and proton $\mathrm{H}^{+}$ATPase (OST2 and AHA11). Among black poplars guard cells, these 
TABLE 2 Summary of the genotype, water treatment, time of day, and leaf side effect on stomatal conductance $(n=6)$, guard cell element content $(n=6)$, and expression of genes of interest $(n=4)$

\begin{tabular}{|c|c|c|c|c|c|c|c|c|c|c|}
\hline & $\begin{array}{l}\text { Genotype } \\
\text { (G) }\end{array}$ & $\begin{array}{l}\text { Water } \\
\text { treatment }(T)\end{array}$ & $\begin{array}{l}\text { Time of day } \\
\text { (D) }\end{array}$ & $\begin{array}{l}\text { Leaf side } \\
\text { (S) }\end{array}$ & $\begin{array}{l}\text { Interaction } \\
\mathrm{G}: \mathrm{T}\end{array}$ & $\begin{array}{l}\text { Interaction } \\
\text { G:D }\end{array}$ & $\begin{array}{l}\text { Interaction } \\
\text { G:S }\end{array}$ & $\begin{array}{l}\text { Interaction } \\
\mathrm{T}: \mathrm{D}\end{array}$ & $\begin{array}{l}\text { Interaction } \\
\mathrm{T}: \mathrm{S}\end{array}$ & $\begin{array}{l}\text { Interaction } \\
\text { D:S }\end{array}$ \\
\hline$g_{\mathrm{s}}$ & $<.001$ & .002 & $<.001$ & $<.001$ & ns & .023 & ns & ns & ns & ns \\
\hline Mg content & $<.001$ & ns & .043 & ns & ns & ns & ns & ns & ns & ns \\
\hline P content & $<.001$ & ns & .003 & $<.001$ & .032 & ns & ns & ns & ns & ns \\
\hline $\mathrm{K}$ content & $<.001$ & ns & ns & .001 & ns & ns & .015 & ns & ns & ns \\
\hline Ca content & $<.001$ & ns & ns & $<.001$ & .008 & ns & ns & ns & ns & ns \\
\hline An/Cat & $<.001$ & ns & .001 & .003 & ns & ns & ns & ns & ns & ns \\
\hline $\mathrm{ABI} 1$ & $<.001$ & ns & ns & .002 & .004 & ns & ns & ns & ns & .03 \\
\hline AHA11 & $<.001$ & ns & $<.001$ & ns & .027 & ns & ns & ns & ns & ns \\
\hline CA4 & $<.001$ & ns & ns & $<.001$ & ns & ns & ns & .024 & ns & ns \\
\hline CAX1 & ns & ns & ns & $<.001$ & ns & ns & ns & .029 & ns & ns \\
\hline CAX1.6 & $<.001$ & ns & ns & $<.001$ & .042 & ns & ns & ns & ns & ns \\
\hline KAT1.2 & $<.001$ & ns & .031 & $<.001$ & $<.001$ & ns & .007 & ns & ns & ns \\
\hline КАТЗ & $<.001$ & .005 & $<.001$ & ns & ns & ns & ns & ns & ns & ns \\
\hline NCED3.1 & $<.001$ & ns & .023 & $<.001$ & ns & ns & ns & ns & ns & ns \\
\hline NCED3.2 & $<.001$ & ns & .049 & .013 & .022 & ns & ns & ns & ns & ns \\
\hline NHX1.13 & $<.001$ & ns & ns & ns & ns & .015 & .004 & ns & ns & ns \\
\hline OST1 & $<.001$ & .034 & .001 & $<.001$ & .01 & ns & $<.001$ & ns & ns & ns \\
\hline PIP2.5 & $<.001$ & ns & .009 & ns & ns & ns & .003 & ns & ns & ns \\
\hline PYL2 & $<.001$ & ns & ns & ns & ns & .048 & ns & ns & ns & ns \\
\hline PYL4 & $<.001$ & 0.008 & ns & ns & .037 & ns & ns & ns & ns & ns \\
\hline PYL8 & $<.001$ & ns & .032 & $<.001$ & .015 & ns & .003 & ns & ns & ns \\
\hline SLAC1 & $<.001$ & 0.018 & ns & .016 & .039 & ns & .008 & ns & ns & ns \\
\hline TIP1.3 & $<.001$ & ns & .001 & ns & .02 & ns & ns & ns & ns & ns \\
\hline TIP1.4 & $<.001$ & ns & ns & ns & .004 & ns & .009 & ns & ns & ns \\
\hline TIP2.1 & $<.001$ & ns & .005 & .049 & ns & .001 & ns & ns & ns & ns \\
\hline TIP2.2 & $<.001$ & ns & ns & ns & ns & ns & ns & ns & ns & ns \\
\hline
\end{tabular}

${ }^{a}$ Note. A type two factorial analysis of variance design with first-order interactions was used. Normalized transcript levels were transformed with a logarithm function of base 2 in order to achieve a normal distribution of the data.

${ }^{\text {b}}$ Abbreviations: $g_{s}$, stomatal conductance to water vapour; An/Cat, ratio of anions over cations (i.e., $\mathrm{P}$ and $\mathrm{Cl}$ over $\mathrm{Na}, \mathrm{Mg}, \mathrm{K}$, and Ca); $\mathrm{ns}$, not significant. ${ }^{*} P<.05 .{ }^{* *} P<.01 .{ }^{* * *} P<.001$.

genes were either similarly or more expressed in $6 \mathrm{~J} 29$ than in N38 (AKT2, OST2, and SLAC1). As to vacuolar $\mathrm{Ca}^{2+}$ antiporters, although transcripts accumulation for CAX1 did not show any significant genotype effect, CAX1.6 was on average 161 times more accumulated in the guard cells of hybrid poplars than in the black poplars. The same pattern was found for the vacuolar $\mathrm{Na}^{+} / \mathrm{H}^{+}$antiporter $\mathrm{NHX1.13}$. Its mRNA levels were also high in Carpaccio, compared with I214. Interestingly, NHX1.13 expression correlated to the $\mathrm{Na}$ content in guard cells (Figure 4, $P<.001, R^{2}=.35$ ). Targeted aquaporins (PIPs and TIPS) mRNA were consistently expressed at the lowest levels in 1214 , with 


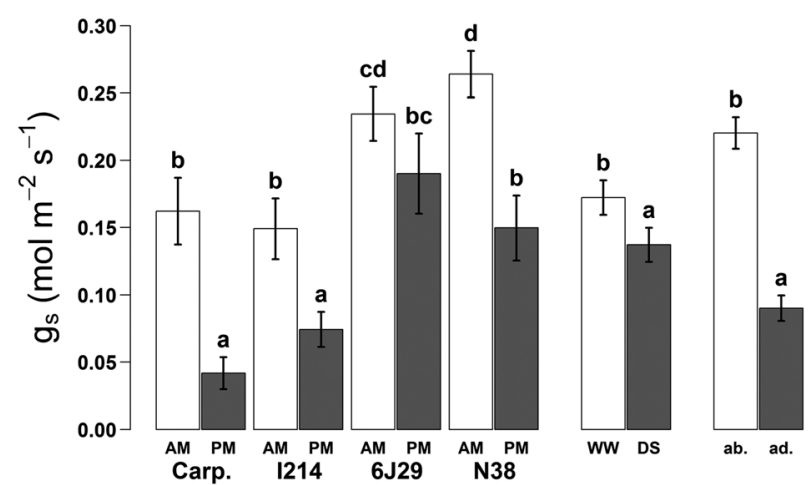

FIGURE 1 Stomatal conductance of four poplar genotypes under contrasting water availability. Each leaf side has been measured separately once in the morning and once in the afternoon (10:30 a.m. and 3:00 p.m.). Carpaccio and 1214 are Populus deltoides $\times$ Populus nigra, whereas $6 \mathrm{~J} 29$ and N38 are P. nigra genotypes. White and grey coloured bars show the contrasts used for statistical design. Letters show significant differences among groups for the genotype-time of day interaction, the water treatment and the leaf side $(P<.05)$

the notable exception of TIP2.1, which was expressed at the highest level in 1214 guard cells (Figure S2u-aa).

\subsection{Impact of water availability on element content and transcript accumulation in guard cells}

$\mathrm{Cl}$ was the only element whose content in the guard cells was significantly $13 \%$ higher in the drought-stressed trees across all genotypes (Figure $\mathrm{S} 1 \mathrm{~d}, \mathrm{P}=.003$ ). Moreover, the guard cells $\mathrm{Cl}$ content was positively correlated with $g_{s}$ when controlling for genotype and water treatment differences (Figure 5, partial $R^{2}=.15, P<.001$ ). Other modifications of element content in response to water regime were genotype specific. The guard cells of $\mathrm{I} 214$ had a P content $11 \%$ lower under drought (for well-watered and drought-stressed trees, respectively: 1.92 and $1.71 \mathrm{mg} \mathrm{g}^{-1}, P=.011$, Figure S1c). Among black poplars, 6J29 and N38 exhibited an increased guard cells Ca content, respectively, $15 \%$ and $13 \%$ higher in the drought-stressed than in the well-watered trees (for control and drought-stressed, respectively, 6J29: 4.92 and $5.78 \mathrm{mg} \mathrm{g}^{-1}, P=.028$; N38: 6.60 and $7.55 \mathrm{mg} \mathrm{g}^{-1}, P=$ .015 , Figure S1f). Neither $\mathrm{K}$ nor any other element in guard cells were under a significant effect of the water regime, either as a main effect or as part of an interaction ( $P>.075$, Table 2$)$.

With respect to the normalized transcript accumulation, the water regime was highly genotype specific as 14 of 27 genes showed a significant interaction between the two factors (Table 2, Figure S2). Only KAT3 and PIP2.1 mRNA levels were significantly lower and higher, respectively, in the drought-stressed trees than in the control, in all genotypes $(P<.006$, Figure S2n-v). Concerning the hybrid poplars, the expression of three genes was down-regulated in response to water stress in the guard cells of Carpaccio (KAT1.2, SLAC1, and TIP1.4) but only two in the guard cells of I214 (AHA11 and TIP1.3). For 6J29, the expression of PYL8, CA1, and PIP1.2 was up-regulated in response to water stress. N38 showed the widest responsiveness to water stress. The expression of PYL4 and TIP1.3 was significantly down-regulated, whereas the expression of ABI1, OST1, AKT2, KAT1.2, and PIP1.2 was up-regulated under water stress.

\subsection{Diurnal and leaf side differences of element content in guard cells}

The PCA highlighted four groups consisting of every paired modality of the time of day and leaf side (Figure 6). The first and second axis explained $36.1 \%$ and $24.7 \%$ of the total variance with the third

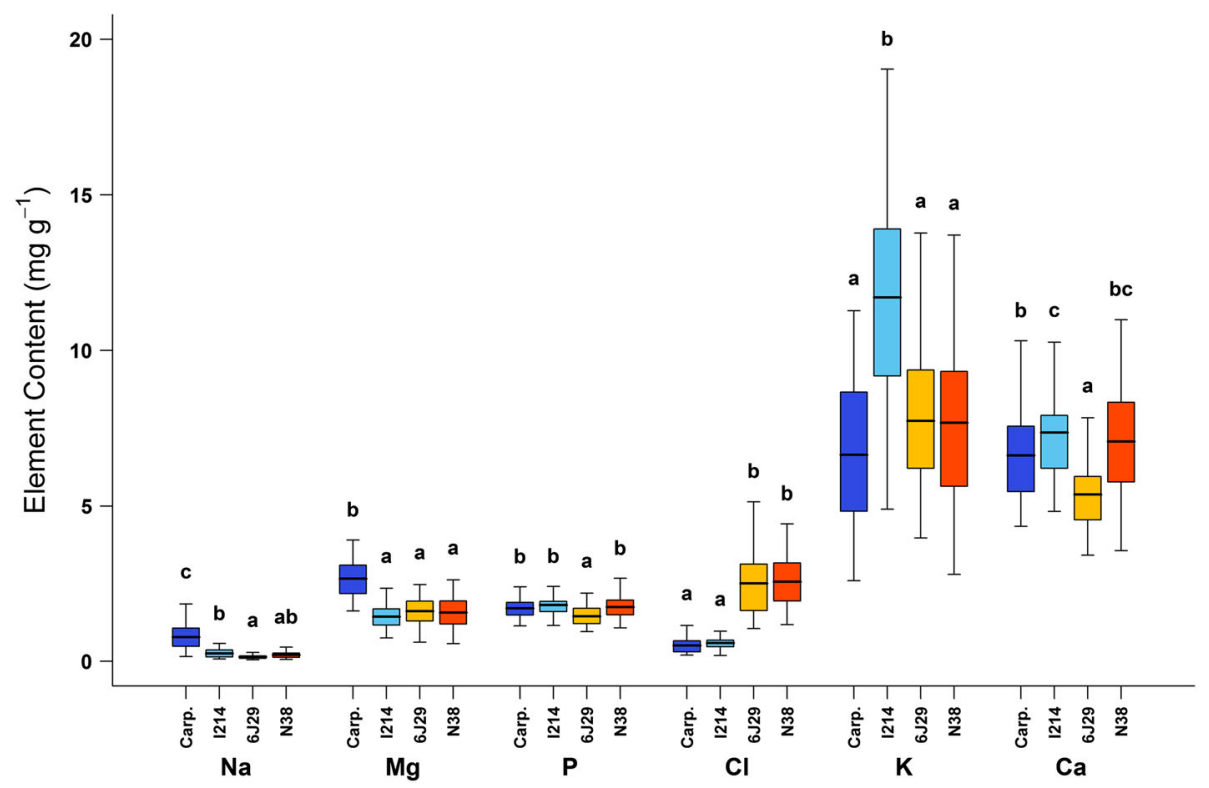

FIGURE 2 Guard cell element content of four poplar genotypes. Carpaccio and I214 are Populus deltoides $\times$ Populus nigra, whereas 6 J29 and N38 are P. nigra genotypes (in dark and light blue, yellow and orange, respectively). Values inside each box are the genotypic mean expressed as "per mille" of dry mass, or $\mathrm{mg} \mathrm{g}^{-1}(n=42-48)$. Boxes and bars show the 10th, 25th, 75th, and 90th percentiles. Letters show significant differences by post hoc contrast among the four genotypes for each element [Colour figure can be viewed at wileyonlinelibrary.com] 


\begin{tabular}{|c|c|c|c|c|}
\hline $0.00019 a$ & $0.0001 \mathrm{a}$ & $0.00018 a$ & $0.0025 \mathrm{~b}$ & NCED3. \\
\hline $0.000007 \mathrm{a}$ & $0.0000051 \mathrm{a}$ & $0.0003 b$ & $0.000002 a$ & NCED3.2 \\
\hline $0.37 a$ & $1 \mathrm{~b}$ & $1.3 \mathrm{~b}$ & $0.47 a$ & $A B \mid 1$ \\
\hline $0.13 a$ & $0.24 b$ & $0.61 \mathrm{c}$ & $0.22 b$ & OST1 \\
\hline $0.19 a$ & $18 d$ & $0.93 b$ & $8.9 c$ & PYL2 \\
\hline $0.028 \mathrm{a}$ & $0.058 b$ & $0.02 \mathrm{a}$ & $0.061 \mathrm{~b}$ & PYL4 \\
\hline $0.14 \mathrm{a}$ & $2.3 b$ & $0.19 a$ & $0.26 a$ & PYL8 \\
\hline $2.8 \mathrm{~b}$ & $0.88 a$ & $8 \mathrm{c}$ & $0.83 a$ & $C A 1$ \\
\hline $0.071 \mathrm{~b}$ & $0.04 a$ & $0.077 \mathrm{~b}$ & $0.21 \mathrm{c}$ & CA4 \\
\hline $0.24 \mathrm{c}$ & $0.035 a$ & $0.17 \mathrm{~b}$ & $0.75 d$ & PHOT1 \\
\hline $0.91 \mathrm{c}$ & $0.29 b$ & $0.074 \mathrm{a}$ & $4.3 \mathrm{~d}$ & РНОT2 \\
\hline $0.0036 \mathrm{~b}$ & $0.00059 a$ & $0.0085 \mathrm{~b}$ & $0.00098 a$ & AKT2 \\
\hline $0.016 a$ & $0.019 a$ & $0.031 \mathrm{~b}$ & $0.034 \mathrm{~b}$ & KAT1.2 \\
\hline $0.16 \mathrm{c}$ & $0.013 a$ & $0.035 b$ & $0.036 \mathrm{~b}$ & KAT3 \\
\hline $0.052 \mathrm{~d}$ & $0.0017 \mathrm{a}$ & $0.033 \mathrm{c}$ & $0.0059 \mathrm{~b}$ & OST2 \\
\hline $0.017 \mathrm{~b}$ & $0.0063 a$ & $0.042 \mathrm{c}$ & $0.038 \mathrm{c}$ & AHA11 \\
\hline $0.000079 \mathrm{~b}$ & $0.000052 a b$ & $0.016 \mathrm{c}$ & $0.000015 a$ & SLAC1 \\
\hline $0.00013 \mathrm{a}$ & $0.00047 a$ & $0.0001 \mathrm{a}$ & $0.00017 \mathrm{a}$ & $C A X 1$ \\
\hline $0.0062 b$ & $0.0025 b$ & $0.000033 a$ & $0.000021 a$ & CAX1.6 \\
\hline $0.019 \mathrm{~d}$ & $0.0068 \mathrm{c}$ & $0.00039 a$ & $0.0021 \mathrm{~b}$ & $N H \times 1.13$ \\
\hline $0.4 \mathrm{~d}$ & $0.023 a$ & $0.2 \mathrm{c}$ & $0.071 \mathrm{~b}$ & PIP1.2 \\
\hline $0.056 \mathrm{~b}$ & $0.0002 a$ & $0.46 d$ & $0.25 \mathrm{c}$ & PIP2.1 \\
\hline $0.0018 b$ & $0.0007 \mathrm{a}$ & $0.026 \mathrm{~d}$ & $0.011 \mathrm{c}$ & PIP2.5 \\
\hline $2.2 \mathrm{~b}$ & $0.043 \mathrm{a}$ & $2.7 \mathrm{c}$ & $4.6 \mathrm{~d}$ & TIP1.3 \\
\hline $0.0049 b$ & $0.0012 a$ & $0.0021 a$ & $0.031 \mathrm{c}$ & TIP1.4 \\
\hline $0.00062 a b$ & $0.0065 c$ & $0.0028 \mathrm{bc}$ & $0.00033 a$ & TIP2.1 \\
\hline $0.000012 b$ & $0.00000077 \mathrm{a}$ & $0.0000016 a$ & $0.046 \mathrm{c}$ & $T I P 2.2$ \\
\hline Carp. & 1214 & $6 J 29$ & N38 & \\
\hline
\end{tabular}

FIGURE 3 Guard cell transcript accumulation heatmap of four poplar genotypes. Carpaccio and I214 are Populus deltoides $\times$ Populus nigra, whereas $6 J 29$ and N38 are P. nigra genotypes. Values inside each box are back-transformed means by genotype of normalized transcript accumulation $(n=2-4)$. Colors range from white to orange to dark red to show the lowest, middling, and highest overall normalized expression values. Letters show significant differences by post hoc contrast among the four genotypes for each gene [Colour figure can be viewed at wileyonlinelibrary.com]

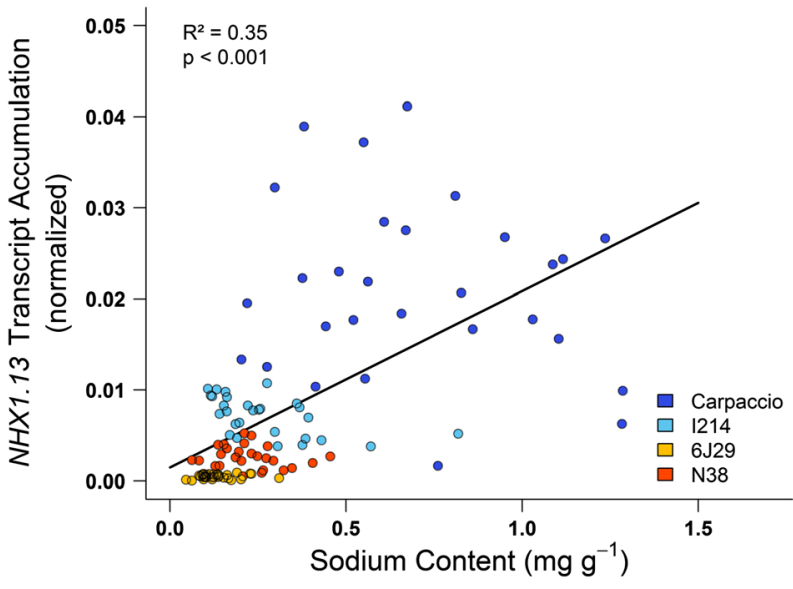

FIGURE 4 Correlation between NHX1.13 normalized transcript accumulation and sodium content (as "per mille" of dry mass) inside the guard cells of four poplar genotypes. Carpaccio and I214 are Populus deltoides $\times$ Populus nigra, whereas 6J29 and N38 are P. nigra genotypes (in dark and light blue, yellow and orange, respectively; $n=$ 115) [Colour figure can be viewed at wileyonlinelibrary.com]

accounting for less than 14\% (not shown). P and Ca content in the guard cells contributed the most to the first axis, whereas the An/ Cat ratio, $\mathrm{Cl}$, and $\mathrm{K}$ content contributed the most to the second axis.

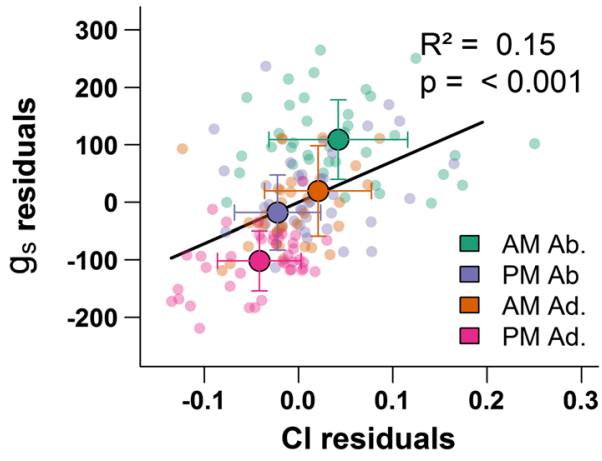

FIGURE 5 Correlation between the stomatal conductance and the chlorine content inside the guard cells once the genotype and water treatment effect is taken into account. Data used are residuals of a linear model with genotype and water treatment as main effect, chlorine content as independent variable, and stomatal conductance as dependent variable $(n=10-22)$ [Colour figure can be viewed at wileyonlinelibrary.com]

Focusing on the first two axis, the four groups formed a diagonal line parallel to the $\mathrm{Cl}$ and $\mathrm{Mg}$ content and to the supplementary variable $g_{s}$. The group associated with the abaxial side in the morning was positively related to these variables, whereas the group formed 


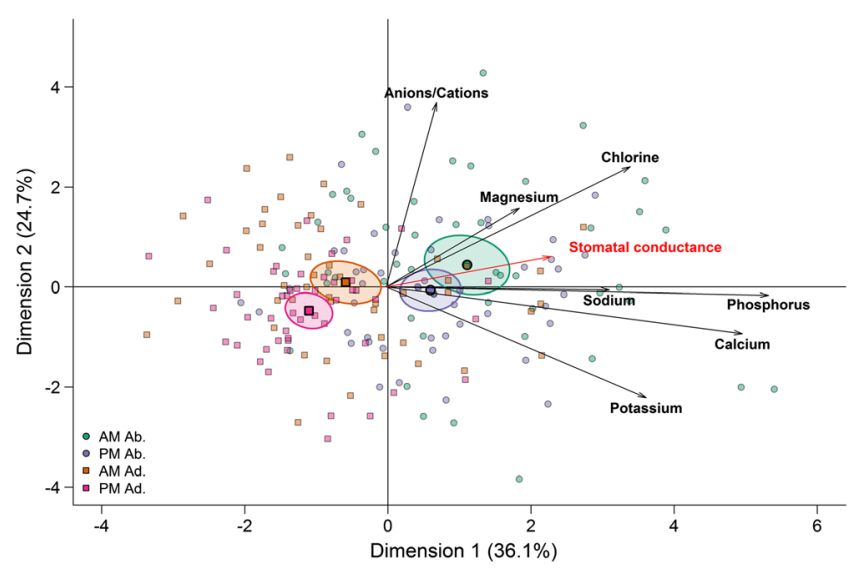

FIGURE 6 Principal component analysis of guard cell element content for each leaf side and time of day. Data used are residuals of linear models with genotype as main effect and each element content as dependent variable $(n=48)$. Stomatal conductance was added as a supplementary variable (in red). Mean points and confidence ellipse are shown. Circles and squares are for the abaxial and adaxial side respectively. Green and orange are for the morning and blue and pink are for the afternoon [Colour figure can be viewed at wileyonlinelibrary.com]

by the data associated to the adaxial side in the afternoon was negatively related to them. The leaf sampled in the morning showed overall a higher $\mathrm{Mg}, \mathrm{P}$, and $\mathrm{Cl}$ content in the guard cells and a higher $\mathrm{An} / \mathrm{Cat}$ ratio than in the leaf sampled in the afternoon (Figure S1b,c, d,g; $P=.043, P=.003, P=.009$, and $P<.001$, respectively). The afternoon decrease ranged from $7 \%$ for $\mathrm{P}$ to $13 \%$ for $\mathrm{Cl}$. Moreover, a higher amount of element was found in the guard cells on the abaxial side than on the adaxial side, with a noticeable exception of the $\mathrm{Mg}$ content $(P=.07)$. $\mathrm{P}, \mathrm{Ca}$, and the ratio $\mathrm{An} / \mathrm{Cat}$ were, respectively, $15 \%, 17 \%$, and $10 \%$ more abundant on the abaxial side $(P<.003) . \mathrm{Cl}$ and $\mathrm{K}$ were also significantly higher on the abaxial side of black poplars (Figure S1d,e). Similar trends, however not significant, were observed in hybrid poplars, as well as a $98 \%$ higher $\mathrm{Na}$ content in the abaxial guard cells of Carpaccio, compared with the adaxial side (Figure S1a, $P<.001$ ).

\subsection{Diurnal and leaf side differences of guard cells transcript accumulation in guard cells}

Because the PCA on the guard cells element content revealed a strong structuration of sampling modalities (Figure 6), we performed a similar analysis on the gene expression for the 27 studied genes (Figure 7). The first three axis explained $21.3 \%, 13.1 \%$, and $7.6 \%$ of the total variance. Among the genes contributing the most to the first axis, we found genes involved in the ABA biosynthesis and signalling pathways (NCED3.1, NCED3.2, ABI1, OST1, and PYL8), $\mathrm{K}^{+}$channels (AKT2 and KAT1.2), and some of the aquaporins (PIP1.2, PIP2.5, TIP1.4, and TIP2.1). The genes contributing highly to the second axis were those encoding $\mathrm{H}^{+}$-ATPase (AHA11 and OST2), $\mathrm{Ca}^{2+}$ vacuolar antiporters (CAX1 and CAX1.6), $\mathrm{K}^{+}$channels (KAT1.2 and KAT3), and NHX1.13. Similar to the PCA on guard cells element content (Figure 6), the four modalities composed by the crossed factors leaf sides and time of day were even more clearly separated by the first two axis, compared with the element content. Morning and afternoon measures were separated on the upward diagonal, whereas leaf sides were separated on the downward diagonal. Overall, the differences between time of day were related to the expression levels of gene encoding $\mathrm{H}^{+}$-ATPase and aquaporins, whereas the differences of leaf sides could be ascribed to genes associated mostly with the ABA response, $\mathrm{Ca}^{2+}$ vacuolar antiporters, and $\mathrm{K}^{+}$channels.

Out of the 27 genes we tested, 20 showed some degree of differential expression in the guard cells between the morning and the afternoon (Table 2, Figure S2). Only three genes were overall less expressed in the afternoon (OST1, KAT1.2, and KAT3) than in the morning by $16 \%, 17 \%$, and $22 \%$, respectively (Figure S2d,m,n). The remaining 17 genes were expressed at the highest level in the afternoon. This included both NCEDs (NCED3.1 and NCED3.2), both $\mathrm{H}^{+}$-
FIGURE 7 Principal component analysis of guard cell normalized transcript accumulation for each leaf side and time of day. Data used are residuals of linear models with genotype as main effect and each transcript as dependent variable ( $n=30-31$ ). Stomatal conductance was added as a supplementary variable (in red). Mean points and confidence ellipse are shown. Circles and squares are for the abaxial and adaxial side, respectively. Green and orange are for the morning and blue and pink are for the afternoon [Colour figure can be viewed at wileyonlinelibrary. com]

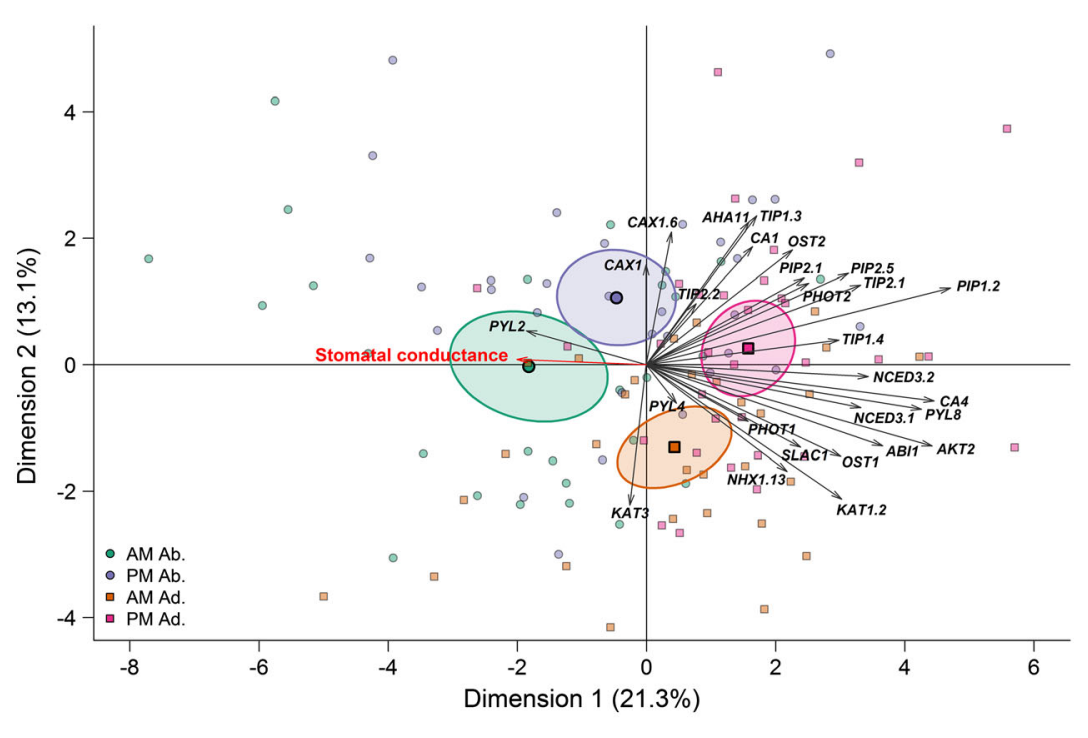


ATPase (OST2 and AHA11), the three tested PIPs (PIP1.2, PIP2.1, and PIP2.5) as well as PYL8, PHOT2, and TIP1.3. ABI1 normalized mRNA levels were higher in the afternoon but only in the guard cells on the abaxial side (Figure S2c, $P=.004$ ). Few significant interactions occurred between genotype and times of day. Both NHX1.13 and TIP2.1 transcripts levels were higher in the afternoon, but in the guard cells of hybrid poplars $(P<.05)$ or of black poplars $(P<.002)$, respectively (Figure S2t,z). Both AKT2 and PYL2 genes were more expressed in the afternoon but only in the guard cells of I214 and N38 $(P<.04)$, respectively (Figure S2e,I).

With respect to the transcripts levels between leaf sides, 18 of the 27 tested genes exhibited a differential expression. In general, we observed the highest expression in the guard cells on the adaxial side of the leaf. Solely, CAX1 and CAX1.6 genes were, respectively, 12.6 and 10.1 times more expressed in the guard cells on the abaxial side than on the adaxial side (Figure $\mathrm{S} 2 \mathrm{r}, \mathrm{s}, P<.001$ ). The same pattern was found for TIP1.3 and for PIP2.5 but only in I214 (Figure S2w,x). The tested NCEDs transcripts levels were 13.5 and 6.8 times more abundant on the adaxial side $(P<.01)$. Similarly, the two $ß$-carbonic anhydrases (CA1 and CA4), PHOT1 and ABI1 were also overall more expressed on the adaxial side, the accumulation of $A B I 1$ transcripts being only significant in the morning (Figure $\mathrm{S} 2 \mathrm{c}, P=.002$ ). A number of genes showed a genotype-specific differential expression between leaf sides. OST1, PYL8, AKT2, and KAT1.2 genes were more expressed in the adaxial guard cells only in Carpaccio and N38. TIP1.4 mRNA level was higher in the guard cells on the adaxial side in Carpaccio. SLAC1, NHX1.13, PIP1.2, and PIP2.5 genes exhibited the same pattern in N38 only. PYL8 was also 3.3 times more expressed in the guard cells on the adaxial side than on the abaxial side of $6 J 29(P=.013)$.

\section{4 | DISCUSSION}

\subsection{Genotypic diversity of element content and gene expression in the guard cells}

Our study focused on the relationships between guard cell element content, expression of genes of interest, and stomatal conductance. By modulating the water regime, leaf sides, and times of day on four poplar genotypes, we intended to gain insight into the molecular drivers of gas exchange regulation and the unique physiology of guard cells.

We found a tremendous diversity for both element content and gene expression in the guard cells of four poplar genotypes. This adds to previous investigations highlighting the considerable diversity of transcript accumulation and responses to environmental factors in distinct organs of poplars (Bizet et al., 2015; Cohen et al., 2013; Dumont et al., 2014; Wilkins et al., 2009). Interestingly, Carpaccio exhibited the lowest expression of genes related to ABA biosynthesis and signalling pathways, especially compared with 1214 . This was not associated with a lower plasticity of stomatal closure under drought, as previous studies found a lack of stomatal response under various water deficits in 1214 but not in Carpaccio (Durand et al., 2019; Muller \& Lambs,
2009). Instead, exogenous supply of ABA to the 1214 clone induced leaf abscission (Chen et al., 1997), which may be part of its drought response (Giovannelli et al., 2007). Additionally, we found a lower expression for the genes encoding $\mathrm{K}^{+}$channels, $\mathrm{H}^{+}$-ATPase, and aquaporins in 1214. These differences could in theory contribute to a reduced stomatal control by limiting the exchange of solutes and water across the plasma membrane. However, of the four genotypes studied, 1214 showed the highest stomatal density and the smallest stomata (Durand et al., 2019). As such, one could expect that not only less water is required to modify the guard cell turgescence but a smaller change in aperture added over the whole leaf could result in a massive change in stomatal conductance. Durand et al. (2019) also showed that 1214 had the fastest stomatal closing speed; here we found that it may not be due to an increased expression of genes encoding transporters on the guard cell plasma membrane.

Along with differences in transcript accumulation, we found evidence of a genotypic diversity of elements contributing to stomatal movements. Little is known on this topic in poplars as the majority of studies focus only on three species (Assmann, 1993), namely, A. thaliana (L.), Commelina communis (L.), and Vicia faba (L.). NHX1.13 encodes a vacuolar $\mathrm{Na}^{+}$and $\mathrm{K}^{+}$transporter that has been shown to regulate cell turgor and stomatal function in A. thaliana (Barragan et al., 2012). The higher amount of $\mathrm{Na}$ in the guard cells of hybrid poplars, linked with higher NHX1.13 mRNA levels, highlights the importance of this element for stomatal control in these genotypes. Because $\mathrm{K}^{+}$channels and some aquaporins may be permeable to $\mathrm{Na}^{+}$ as well (Byrt et al., 2017; Jezek \& Blatt, 2017), one could speculate that these transporters have an increased permeability for $\mathrm{Na}^{+}$compared with black poplars. In contrast, the higher $\mathrm{Cl}$ content in black poplars emphasize its role in stomatal function in these genotypes. Both malate and $\mathrm{Cl}^{-}$act as counter-ions to balance the uptake of $\mathrm{K}^{+}$ into the guard cells in various proportions depending on species, $\mathrm{Cl}$ availability, and starch metabolism (Raschke \& Schnabl, 1978; Santelia \& Lawson, 2016).

\section{2 | Impact of water availability}

A relatively weak effect of the water regime occurred on element content and normalized mRNA levels, especially as compared with the other tested factors (Table S3). This might be related to the leaf sampling, which occurred 21 days after the start of a mild drought, when short-term gene expression responses were replaced by acclimation of physiological processes. Similarly in Populus tremula, few changes in the expression of genes of interest were found in leaves sampled more than 20 days after the start of the drought (Possen et al., 2011). The drought response at the transcript level was highly genotype specific, in agreement with transcriptomic studies on poplar genotypes, showing divergent expression profiles under drought even when the physiological response was similar (Cohen et al., 2010; Wilkins et al., 2009). PIP2.1 was the only up-regulated gene in all four genotypes under drought. Despite not always being the case, similar results were found on various hybrid poplars (Almeida-Rodriguez, 
Cooke, Yeh, \& Zwiazek, 2010; Cohen et al., 2013). AtPIP2.1 and ZmPIP2.1 increased water permeability when expressed in Xenopus oocytes and protoplasts of Lilium longifolium pollen (Lopez et al., 2003; Sommer et al., 2008). Moreover, AtPIP2.1 was related to ABAinduced stomatal closure, mediated by OST1 by increasing guard cell permeability for water enabling its efflux (Grondin et al., 2015; Maurel, Verdoucq, \& Rodrigues, 2016). Increasing PIP2.1 expression under drought may allow for a faster stomatal closure.

Under drought, there was an increased $\mathrm{Ca}$ content in black poplars together with a higher $\mathrm{Cl}$ content for all genotypes. During stomatal closure, free $\mathrm{Ca}^{2+}$ entering the cytosolic spaces of guard cells is known to be responsible for the inactivation of inward-rectifying $\mathrm{K}^{+}$channels in V. faba (Grabov \& Blatt, 1999; Schroeder \& Hagiwara, 1989) and the activation of anion channels, such as SLAC1 when expressed in Xenopus laevis oocytes (Geiger et al., 2010). However, $\mathrm{Ca}^{2+}$ elevation in the cytosol has been found to be mostly due to influx from the vacuole and the endoplasmic reticulum as opposed to entry from the apoplast (Chen et al., 2012). Unfortunately, we are not able to localize specific subcellular compartments. Concurrently to the increased $\mathrm{Ca}$ content, the $\mathrm{Cl}$ content increased as well under drought. This suggests that an increased solute concentration in guard cells may be in part a response to a decline in leaf water content in poplars under drought (Guo, Zhang, \& Huang, 2010; Marron et al., 2003).

\section{3 | Leaf side and time of day shape guard cell element content and transcript accumulation}

Gene expression and element content in the guard cells followed opposite patterns over the leaf and along the day. Although stomatal conductance and element content reached a maximum on the abaxial side in the morning, transcript levels was overall at the lowest. The same pattern occurred, but reversed on the adaxial side in the afternoon

There was no significant change of $\mathrm{K}$ content in guard cells of various apertures despite the overall element content being higher in more opened stomata, particularly with the increased $\mathrm{Cl}$ content (Figure 6). These results were checked by $\mathrm{X}$-ray microanalyses under cryogenic conditions $\left(-145^{\circ} \mathrm{C}\right)$. Both techniques (cryo and freeze-dried samples) showed no difference of $\mathrm{K}$ content inside the guard cells between leaves with markedly different stomatal conductance. The lack of decrease in $\mathrm{K}$ concentration in stomatal guard cells with lower stomatal aperture was quite unexpected as $\mathrm{K}$ is known to be of primary importance for stomatal movements. A previous study on hybrid poplar genotypes found an increased $\mathrm{K}$ content in guard cells under ozone while having lower $g_{s}$ (Dumont et al., 2014). Langer et al. (2004) found only a $25 \%$ decrease in guard cell $\mathrm{K}$ content between $P$. tremula $\times$ Populus tremuloides leaves grown under $\mathrm{CO}_{2}$-free environment and leaves in the dark subjected to $100-\mu \mathrm{M} A B A$, resulting in an $80 \% g_{s}$ decrease.

In our study, stomatal conductance was impacted by the different water regimes, leaf sides, and times of day. Because the difference in $g_{s}$ between well-watered and drought-stressed poplars was relatively small, differences of $\mathrm{K}$ content would most likely also be relatively small. Consequently, such small changes may not be identified using this technique, especially when considering the many roles $\mathrm{K}$ has in multiple processes, from homeostasis to enzymes activation (Clarkson \& Hanson, 1980). Despite a significantly lower $\mathrm{K}$ content on the adaxial side of the leaf, differences in $g_{s}$ between leaf sides may be predominantly attributed to differences of stomatal density rather than apertures (Durand et al., 2019). Hence, differences of $g_{s}$ between times of day were our best candidate to find corresponding differences in guard cell $\mathrm{K}$ content. However, unlike stomatal opening, it has been proposed that stomatal closure in the afternoon may be more related to sucrose than K (Amodeo, Talbott, \& Zeiger, 1996; Granot \& Kelly, 2019; Kottapalli et al., 2018; Talbott \& Zeiger, 1996). When the rate of sucrose production is higher than its loading into the phloem, excess sucrose accumulate in the apoplast and may enter guard cells (Ewert, Jr, Zhang, Aghoram, \& Riddle, 2000; Kang, Outlaw, Andersen, \& Fiore, 2007), inducing stomatal closure mediated by hexokinases (Kelly et al., 2013). Clearly, more research is needed to decipher changes of element content in poplar guard cells related to stomatal movements, which will necessitate the input of multiple techniques.

Diurnal rhythms in transcript accumulation were reported by previous studies for the expression of aquaporin-encoding genes and genes involved in ABA regulation. In contrast to our findings, whole leaves and roots generally have an increased accumulation of aquaporin transcripts in the morning, or in the few hours following an increase of light (Hachez, Heinen, Draye, \& Chaumont, 2008; Henzler et al., 1999; Lopez et al., 2003; Lopez et al., 2013; Vandeleur et al., 2009). On the other hand, even if leaf ABA concentrations tend to increase at the end of the day (Novakova et al., 2005), the genes involved in the ABA-related pathways seem to present a diversity of diurnal rhythms in leaves (Seung et al., 2012). Despite their close proximity to mesophyll cells, stomata have specific circadian rhythms (Hassidim et al., 2017; Yakir et al., 2011). Given their relatively low proportion in the leaf compared with other cell types, the different expression profile along the day in guard cells compared with whole leaves could result from the cellular complexity of the organ that hides cell-type specific regulations (Nourbakhsh-Rey \& Libault, 2016). In addition to the changes in element content, guard cells are also subjected to $\mathrm{pH}$ variations during stomatal movement. In general, stomatal closure induces cytosolic and vacuolar alkalinization (Irving, Gehring, \& Parish, 1992; Zhang, Dong, Gao, \& Song, 2001), whereas stomatal opening induces acidification (Huang, She, Zhang, \& Zhao, 2013), linked with $\mathrm{H}_{2} \mathrm{O}_{2}$ and $\mathrm{Ca}^{2+}$ signalling during both $\mathrm{ABA}$ and dark-induced stomatal responses (Agurla \& Raghavendra, 2016; Ma \& Niu, 2017). Moreover, external $\mathrm{pH}$ changes strongly altered transcript levels, which was linked to ABA-responsive element motifs in the promoter region of pH-responsive genes (Lager et al., 2010). Little is known about the effect of intracellular $\mathrm{pH}$ on transcript accumulation, and whether or not guard cell movements affect its own expression pattern remains to be established.

Potential differences in the physiology of guard cells between leaf sides is seldom investigated, and even fewer studies compare the 
patterns of transcript accumulation and/or element content. We reported here an overall stronger expression of genes of interest on the adaxial side for a number of genes, including NCEDs and ßcarbonic anhydrases. However, the higher expression of vacuolar $\mathrm{Ca}^{2+}$ antiporters on the abaxial side was associated with a higher $\mathrm{Ca}$ content on this side, in agreement with Dumont et al. (2014). It has been hypothesized that guard cells on each side may have different pathways for $\mathrm{Ca}^{2+}$-mediated signal transduction (Wang, Wu, \& Assmann, 1998). There is evidence of an independent control of gas exchange between leaf sides (Mott, Cardon, \& Berry, 1993; Richardson et al., 2017). Such control would allow amphistomatal leaves to regulate more efficiently in response to the environmental conditions specific to each side. Previously reported thermal and irradiance gradients between leaf surfaces of a few degrees (Buckley, John, Scoffoni, \& Sack, 2015; Clum, 1926; Sheriff, 1979) could result in different perceived environmental conditions between leaf sides (e.g., light, VPD, and temperature), prompting different stomatal control, as was found on poplar clones in response to a change in light and VPD (Ceulemans, Hinckley, \& Impens, 1989; Pallardy \& Kozlowski, 1979). Differences in the intensity and nature of perceived stresses, such as evaporative demand, light, and heat (Urban, Ingwers, McGuire, \& Teskey, 2017) may induce a distinct conjugation of stress between sides, which may affect the synergic or antagonistic response to environmental cues (Bigot et al., 2018). This would result in a different perception and signalization between sides; for example, stomata of Gossypium barbadense (L.) have distinct sensitivity to light between sides linked with different pigment contents (Lu, Quiñones, \& Zeiger, 1993). A different sensitivity between sides would lead to a diversity of gene expression (see Bigot et al., 2018), and element content in the guard cells, which may be a part of what we observed. A stronger gene expression on the adaxial side might be seen as the result of a more extreme condition on the side facing the light source.

In conclusion, even though we found a strong genotypic diversity, our data show how changes in stomatal conductance between leaf sides and time of day are linked to guard cell element content and transcript accumulation profiles in a similar way across the four studied genotypes (Figures 6 and 7). Future technical developments such as cryogenic electron microscopy will allow for an easier element cellular compartmentation. Because stomata are responsible for optimizing carbon gain with regard to water loss, their functions affect not only the plant but the ecosystem as well (Berry, Beerling, \& Franks, 2010). Understanding the specificities of guard cells functioning will further expand our current knowledge of stomatal physiology and their global consequences.

\section{ACKNOWLEDGMENTS}

This work was conducted in the frame of the WATBIO (Development of improved perennial biomass crops for water-stressed environments), a collaborative research project funded from the European Union's Seventh Programme for research, technological development and demonstration under grant agreement 311929. The research received funding from the French National Research Agency through the Laboratory of Excellence ARBRE (ANR-12-LABXARBRE-01). M. D. received a PhD scholarship from the Lorraine Région and EFPA (INRA research department). We thank the nursery of Guéméné Penfao for providing the Euramerican poplar cuttings. The authors acknowledge Marc Villar and Catherine Bastien from the UR0588INRA Unit for access to the referenced P. nigra clones 6J29 and N38 as well as SILVATECH from UMR 1434 SILVA, 1136 IAM, 1138 $B E F$, and 4370 EA LERMAB EEF research centre INRA Grand-Est for its contribution to X-ray microanalyses. SILVATECH facility is supported by the French National Research Agency through the Laboratory of Excellence ARBRE.

\section{CONFLICT OF INTEREST}

The authors declare that the research was conducted in the absence of any commercial or financial relationships that could be construed as a potential conflict of interest.

\section{AUTHOR CONTRIBUTION}

D. L. T., O. B., C. B., M. D., and D. C. developed the experimental design. C. B. carried out the experimental drought set-up. D. L. T. collected leaf porometer data; D. L. T., D. C., I. H., and N. A. sampled the leaves; M. D. performed X-ray microanalysis; M. D., D. C., and I. T. microdissected the stomata and extracted the RNA. N. A. performed cDNA amplification, RT-PCR, and data standardization. M. D., D. L. T., D. C., and I. H. performed data analysis. All contributors were involved in the writing and reviewing of the manuscript.

\section{ORCID}

Didier Le Thiec (D) https://orcid.org/0000-0002-4204-551X

\section{REFERENCES}

Acharya, B. R., \& Assmann, S. M. (2009). Hormone interactions in stomatal function. Plant Molecular Biology, 69(4), 451-462. https://doi.org/ 10.1007/s11103-008-9427-0

Agurla, S., \& Raghavendra, A. S. (2016). Convergence and divergence of signaling events in guard cells during stomatal closure by plant hormones or microbial elicitors. Frontiers in Plant Science, 7(1332). https://doi.org/10.3389/fpls.2016.01332

Almeida-Rodriguez, A. M., Cooke, J. E. K., Yeh, F., \& Zwiazek, J. J. (2010). Functional characterization of drought-responsive aquaporins in Populus balsamifera and Populus simonii $\times$ balsamifera clones with different drought resistance strategies. Physiologia Plantarum, 140(4), 321-333. https://doi.org/10.1111/j.1399-3054.2010.01405.x

Amodeo, G., Talbott, L. D., \& Zeiger, E. (1996). Use of potassium and sucrose by onion guard cells during a daily cycle of osmoregulation. Plant and Cell Physiology, 37(5), 575-579. https://doi.org/10.1093/ oxfordjournals.pcp.a028983

Amsellem, J., Nicaise, G., Blaineau, S., Quintana, C., Escaig, J., Roinel, N., ... Vicario, E. (1983). Microanalyse $\times$ en biologie. Société Française de Microscopie Electronique, Paris.

Assmann, S. M. (1993). Signal transduction in guard cells. Annual Review of Cell Biology, 9(1), 345-375. https://doi.org/10.1146/annurev. cb.09.110193.002021

Barragan, V., Leidi, E. O., Andres, Z., Rubio, L., De Luca, A., Fernandez, J. A., ... Pardo, J. M. (2012). Ion exchangers NHX1 and NHX2 mediate active 
potassium uptake into vacuoles to regulate cell turgor and stomatal function in Arabidopsis. Plant Cell, 24(3), 1127-1142. https://doi.org/ 10.1105/tpc.111.095273

Bauer, H., Ache, P., Lautner, S., Fromm, J., Hartung, W., Al-Rasheid, K. A. S., ... Hedrich, R. (2013). The stomatal response to reduced relative humidity requires guard cell-autonomous ABA synthesis. Current Biology, 23(1), 53-57. https://doi.org/10.1016/j.cub.2012.11.022

Berry, J. A., Beerling, D. J., \& Franks, P. J. (2010). Stomata: Key players in the earth system, past and present. Current Opinion in Plant Biology, 13(3), 232-239. https://doi.org/10.1016/j.pbi.2010.04.013

Bigot, S., Buges, J., Gilly, L., Jacques, C., Boulch, P. L., Berger, M., ... Couée, I. (2018). Pivotal roles of environmental sensing and signaling mechanisms in plant responses to climate change. Global Change Biology, 24(12), 5573-5589. https://doi.org/10.1111/gcb.14433

Bizet, F., Bogeat-Triboulot, M. B., Montpied, P., Christophe, A., Ningre, N., Cohen, D., \& Hummel, I. (2015). Phenotypic plasticity toward water regime: Response of leaf growth and underlying candidate genes in Populus. Physiologia Plantarum, 154(1), 39-53. https://doi.org/ 10.1111/ppl.12271

Bonan, G. B. (2008). Forests and climate change: Forcings, feedbacks, and the climate benefits of forests. Science, 320(5882), 1444-1449. https://doi.org/10.1126/science.1155121

Brodribb, T. J., \& Cochard, H. (2009). Hydraulic failure defines the recovery and point of death in water-stressed conifers. Plant Physiology, 149(1), 575-584. https://doi.org/10.1104/pp.108.129783

Brunner, A. M., Yakovlev, I. A., \& Strauss, S. H. (2004). Validating internal controls for quantitative plant gene expression studies. BMC Plant Biology, 4(1), 14. https://doi.org/10.1186/1471-2229-4-14

Buckley, T. N. (2005). The control of stomata by water balance. New Phytologist, 168(2), 275-291. https://doi.org/10.1111/j.14698137.2005.01543.x

Buckley, T. N., John, G. P., Scoffoni, C., \& Sack, L. (2015). How does leaf anatomy influence water transport outside the xylem? Plant Physiology, 168(4), 1616-1635. https://doi.org/10.1104/pp.15.00731

Byrt, C. S., Zhao, M., Kourghi, M., Bose, J., Henderson, S. W., Qiu, J., ... Tyerman, S. (2017). Non-selective cation channel activity of aquaporin AtPIP2;1 regulated by $\mathrm{Ca} 2+$ and pH. Plant, Cell \& Environment, 40(6), 802-815. https://doi.org/10.1111/pce.12832

Ceulemans, R., Hinckley, T. M., \& Impens, I. (1989). Stomatal response of hybrid poplar to incident light, sudden darkening and leaf excision. Physiologia Plantarum, 75(2), 174-182. https://doi.org/10.1111/ j.1399-3054.1989.tb06165.x

Chaumont, F., \& Tyerman, S. D. (2014). Aquaporins: Highly regulated channels controlling plant water relations. Plant Physiology, 164(4), 1600-1618. https://doi.org/10.1104/pp.113.233791

Chaves, M. M., Maroco, J. P., \& Pereira, J. S. (2003). Understanding plant responses to drought - from genes to the whole plant. Functional Plant Biology, 30(3), 239-264. https://doi.org/10.1071/FP02076

Chen, S. L., Wang, S. S., Altman, A., \& Huttermann, A. (1997). Genotypic variation in drought tolerance of poplar in relation to abscisic acid. Tree Physiology, 17(12), 797-803. https://doi.org/10.1093/treephys/ 17.12.797

Chen, Z.-H., Hills, A., Bätz, U., Amtmann, A., Lew, V. L., \& Blatt, M. R. (2012). Systems dynamic modeling of the stomatal guard cell predicts emergent behaviors in transport, signaling, and volume control. Plant Physiology, 159(3), 1235-1251. https://doi.org/10.1104/pp.112. 197350

Ciais, P., Reichstein, M., Viovy, N., Granier, A., Ogee, J., Allard, V., ... Valentini, R. (2005). Europe-wide reduction in primary productivity caused by the heat and drought in 2003. Nature, 437(7058), 529-533. https://doi.org/10.1038/nature03972

Clarkson, D. T., \& Hanson, J. B. (1980). The mineral nutrition of higher plants. Annual Review of Plant Physiology and Plant Molecular Biology, 31, 239-298. https://doi.org/10.1146/annurev.pp.31.060180.001323

Clum, H. H. (1926). The effect of transpiration and environmental factors on leaf temperatures II. Light intensity and the relation of transpiration to the thermal death point. American Journal of Botany, 13(4), 217-230. https://doi.org/10.1002/j.1537-2197.1926.tb05879.x

Cohen, D., Bogeat-Triboulot, M. B., Tisserant, E., Balzergue, S., MartinMagniette, M. L., Lelandais, G., ... Hummel, I. (2010). Comparative transcriptomics of drought responses in Populus: A meta-analysis of genome-wide expression profiling in mature leaves and root apices across two genotypes. BMC Genomics, 11, 21.

Cohen, D., Bogeat-Triboulot, M. B., Vialet-Chabrand, S., Merret, R., Courty, P. E., Moretti, S., ... Hummel, I. (2013). Developmental and environmental regulation of aquaporin gene expression across Populus species: Divergence or redundancy? PLoS ONE, 8(2), 12.

Coopman, R. E., Jara, J. C., Bravo, L. A., Sáez, K. L., Mella, G. R., \& Escobar, R. (2008). Changes in morpho-physiological attributes of Eucalyptus globulus plants in response to different drought hardening treatments. Electronic Journal of Biotechnology, 11(2), 30-39.

Cowan, I. R., \& Farquhar, G. D. (1977). Stomatal function in relation to leaf metabolism and environment. Symposia of the Society for Experimental Biology, 31, 471-505.

Dai, A. (2012). Increasing drought under global warming in observations and models. Nature Climate Change, 3, 52.

Damsteegt, E. L., McHugh, N., \& Lokman, P. M. (2016). Storage by lyophilization-Resulting RNA quality is tissue dependent. Analytical Biochemistry, 511, 92-96.

Davies, W. J., \& Zhang, J. H. (1991). Root signals and the regulation of growth and development of plants in drying soil. Annual Review of Plant Physiology and Plant Molecular Biology, 42, 55-76. https://doi.org/ 10.1146/annurev.pp.42.060191.000415

de Dios, V. R. (2017). Circadian regulation and diurnal variation in gas exchange. Plant Physiology, 175(1), 3-4. https://doi.org/10.1104/ pp.17.00984

Dodd, I. C. (2005). Root-to-shoot signalling: Assessing the roles of 'up' in the up and down world of long-distance signalling in planta. Plant and Soil, 274(1-2), 251-270. https://doi.org/10.1007/s11104-004-0966-0

Dumont, J., Cohen, D., Gerard, J., Jolivet, Y., Dizengremel, P., \& Le Thiec, D. (2014). Distinct responses to ozone of abaxial and adaxial stomata in three Euramerican poplar genotypes. Plant, Cell and Environment, 37(9), 2064-2076. https://doi.org/10.1111/pce.12293

Durand, M., Brendel, O., Buré, C., \& Le Thiec, D. (2019). Altered stomatal dynamics induced by changes in irradiance and vapour-pressure deficit under drought: Impact on the whole plant transpiration efficiency of poplar genotypes. New Phytologist, 222, 1789-1802. https://doi.org/ 10.1111/nph.15710

Ewert, M. S., Jr, W. H. O., Zhang, S., Aghoram, K., \& Riddle, K. A. (2000). Accumulation of an apoplastic solute in the guard-cell wall is sufficient to exert a significant effect on transpiration in Vicia faba leaflets. Plant, Cell \& Environment, 23(2), 195-203. https://doi.org/10.1046/j.13653040.2000.00539.x

García-Baldenegro, C. V., Vargas-Arispuro, I., Islas-Osuna, M., RiveraDomínguez, M., Aispuro-Hernández, E., \& Martínez-Téllez, M. Á. (2015). Total RNA quality of lyophilized and cryopreserved dormant grapevine buds. Electronic Journal of Biotechnology, 18(2), 134-137. https://doi.org/10.1016/j.ejbt.2015.01.002 
Geiger, D., Scherzer, S., Mumm, P., Marten, I., Ache, P., Matschi, S., ... Hedrich, R. (2010). Guard cell anion channel SLAC1 is regulated by CDPK protein kinases with distinct $\mathrm{Ca} 2+$ affinities. Proceedings of the National Academy of Sciences of the United States of America, 107(17), 8023-8028. https://doi.org/10.1073/pnas.0912030107

Geiger, D., Scherzer, S., Mumm, P., Stange, A., Marten, I., Bauer, H., ... Hedrich, R. (2009). Activity of guard cell anion channel SLAC1 is controlled by drought-stress signaling kinase-phosphatase pair. Proceedings of the National Academy of Sciences, 106(50), 21425-21430. https://doi.org/10.1073/pnas.0912021106

Giovannelli, A., Deslauriers, A., Fragnelli, G., Scaletti, L., Castro, G., Rossi, S., \& Crivellaro, A. (2007). Evaluation of drought response of two poplar clones (Populus×canadensis Mönch 'I-214' and P. deltoides Marsh. 'Dvina') through high resolution analysis of stem growth. Journal of Experimental Botany, 58(10), 2673-2683. https://doi.org/10.1093/ jxb/erm117

Grabov, A., \& Blatt, M. R. (1999). A steep dependence of inward-rectifying potassium channels on cytosolic free calcium concentration increase evoked by hyperpolarization in guard cells. Plant Physiology, 119(1), 277-288. https://doi.org/10.1104/pp.119.1.277

Granot, D., \& Kelly, G. (2019). Evolution of guard-cell theories: The story of sugars. Trends in Plant Science, 24(6), 507-518. https://doi.org/ 10.1016/j.tplants.2019.02.009

Grondin, A., Rodrigues, O., Verdoucq, L., Merlot, S., Leonhardt, N., \& Maurel, C. (2015). Aquaporins contribute to ABA-triggered stomatal closure through OST1-mediated phosphorylation. The Plant Cell, 27(7), 1945-1954. https://doi.org/10.1105/tpc.15.00421

Guo, X. Y., Zhang, X. S., \& Huang, Z. Y. (2010). Drought tolerance in three hybrid poplar clones submitted to different watering regimes. Journal of Plant Ecology, 3(2), 79-87. https://doi.org/10.1093/jpe/rtq007

Gutierrez, L., Mauriat, M., Guenin, S., Pelloux, J., Lefebvre, J. F., Louvet, R., ... Van Wuytswinkel, O. (2008). The lack of a systematic validation of reference genes: A serious pitfall undervalued in reverse transcription-polymerase chain reaction (RT-PCR) analysis in plants. Plant Biotechnology Journal, 6(6), 609-618. https://doi.org/10.1111/ j.1467-7652.2008.00346.x

Hachez, C., Heinen, R. B., Draye, X., \& Chaumont, F. (2008). The expression pattern of plasma membrane aquaporins in maize leaf highlights their role in hydraulic regulation. Plant Molecular Biology, 68(4-5), 337-353. https://doi.org/10.1007/s11103-008-9373-x

Hassidim, M., Dakhiya, Y., Turjeman, A., Hussien, D., Shor, E., Anidjar, A., ... Green, R. M. (2017). CIRCADIAN CLOCK ASSOCIATED1 (CCA1) and the circadian control of stomatal aperture. Plant Physiology, 175(4), 1864-1877. https://doi.org/10.1104/pp.17.01214

Heinen, R. B., Bienert, G. P., Cohen, D., Chevalier, A. S., Uehlein, N., Hachez, C., ... Chaumont, F. (2014). Expression and characterization of plasma membrane aquaporins in stomatal complexes of Zea mays. Plant Molecular Biology, 86(3), 335-350. https://doi.org/10.1007/ s11103-014-0232-7

Henzler, T., Waterhouse, R. N., Smyth, A. J., Carvajal, M., Cooke, D. T., Schaffner, A. R., ... Clarkson, D. T. (1999). Diurnal variations in hydraulic conductivity and root pressure can be correlated with the expression of putative aquaporins in the roots of Lotus japonicus. Planta, 210(1), 50-60. https://doi.org/10.1007/s004250050653

Huang, A. X., She, X. P., Zhang, Y. Y., \& Zhao, J. L. (2013). Cytosolic acidification precedes nitric oxide removal during inhibition of $A B A$-induced stomatal closure by fusicoccin. Russian Journal of Plant Physiology, 60(1), 60-68. https://doi.org/10.1134/S1021443712060076

Huang, D., Wu, W., Abrams, S. R., \& Cutler, A. J. (2008). The relationship of drought-related gene expression in Arabidopsis thaliana to hormonal and environmental factors. Journal of Experimental Botany, 59(11), 2991-3007. https://doi.org/10.1093/jxb/ern155

Intergovernmental Panel on Climate Change (2014). Climate change 2014: Synthesis report. Contribution of working groups I, II and III to the fifth assessment report of the intergovernmental panel on climate change. Geneva, Switzerland: Cambridge University Press. https://doi.org/ 10.1017/СBO9781107415416

Irving, H. R., Gehring, C. A., \& Parish, R. W. (1992). Changes in cytosolic pH and calcium of guard-cells precede stomatal movements. Proceedings of the National Academy of Sciences of the United States of America, 89(5), 1790-1794. https://doi.org/10.1073/pnas.89.5.1790

Jaiprakash, M. R., Pillai, B., Venkatesh, P., Subramanian, N., Sinkar, V. P., \& Sadhale, P. P. (2003). RNA isolation from high-phenolic freeze-dried tea (Camellia sinensis) leaves. Plant Molecular Biology Reporter, 21(4), 465-466. https://doi.org/10.1007/BF02772599

Jansson, S., \& Douglas, C. J. (2007). Populus: A model system for plant biology. Annual Review of Plant Biology, 58, 435-458. https://doi.org/ 10.1146/annurev.arplant.58.032806.103956

Jezek, M., \& Blatt, M. R. (2017). The membrane transport system of the guard cell and its integration for stomatal dynamics. Plant Physiology, 174(2), 487-519. https://doi.org/10.1104/pp.16.01949

Kanemasu, E. T., \& Tanner, C. B. (1969). Stomatal diffusion resistance of snap beans I. Influence of leaf-water potential. Plant Physiology, 44(11), 1547-1552. https://doi.org/10.1104/pp.44.11.1547

Kang, Y. U. N., Outlaw, W. H., Andersen, P. C., \& Fiore, G. B. (2007). Guardcell apoplastic sucrose concentration ? a link between leaf photosynthesis and stomatal aperture size in the apoplastic phloem loader Vicia faba L. Plant, Cell \& Environment, 30(5), 551-558. https://doi. org/10.1111/j.1365-3040.2007.01635.x

Kassam, A. H. (1973). Influence of light and water deficit upon diffusive resistance of leaves of Vicia faba L. New Phytologist, 72(3), 557-570. https://doi.org/10.1111/j.1469-8137.1973.tb04407.x

Kelly, G., Moshelion, M., David-Schwartz, R., Halperin, O., Wallach, R., Attia, Z., ... Granot, D. (2013). Hexokinase mediates stomatal closure. The Plant Journal, 75(6), 977-988. https://doi.org/10.1111/tpj.12258

Kottapalli, J., David-Schwartz, R., Khamaisi, B., Brandsma, D., Lugassi, N., Egbaria, A., ... Granot, D. (2018). Sucrose-induced stomatal closure is conserved across evolution. PLoS ONE, 13(10), e0205359. https://doi. org/10.1371/journal.pone.0205359

Lager, I., Andreasson, O., Dunbar, T. L., Andreasson, E., Escobar, M. A., \& Rasmusson, A. G. (2010). Changes in external pH rapidly alter plant gene expression and modulate auxin and elicitor responses. Plant, Cell and Environment, 33(9), 1513-1528.

Langer, K., Levchenko, V., Fromm, J., Geiger, D., Steinmeyer, R., Lautner, S., ... Hedrich, R. (2004). The poplar K+ channel KPT1 is associated with K + uptake during stomatal opening and bud development. The Plant Journal, 37(6), 828-838. https://doi.org/10.1111/j.0960-7412.2003. 02008.x

Leonhardt, N., Kwak, J. M., Robert, N., Waner, D., Leonhardt, G., \& Schroeder, J. I. (2004). Microarray expression analyses of Arabidopsis guard cells and isolation of a recessive abscisic acid hypersensitive protein phosphatase 2C mutant. Plant Cell, 16(3), 596-615. https://doi. org/10.1105/tpc.019000

Lopez, D., Venisse, J. S., Fumanal, B., Chaumont, F., Guillot, E., Daniels, M. J., ... Gousset-Dupont, A. (2013). Aquaporins and leaf hydraulics: poplar sheds new light. Plant and Cell Physiology, 54(12), 1963-1975. https:// doi.org/10.1093/pcp/pct135

Lopez, M., Bousser, A. S., Sissoeff, I., Gaspar, M., Lachaise, B., Hoarau, J., \& Mahe, A. (2003). Diurnal regulation of water transport and aquaporin gene expression in maize roots: Contribution of PIP2 proteins. Plant 
and Cell Physiology, 44(12), 1384-1395. https://doi.org/10.1093/pcp/ pcg168

Lu, Z., Quiñones, M. A., \& Zeiger, E. (1993). Abaxial and adaxial stomata from Pima cotton (Gossypium barbadense L.) differ in their pigment content and sensitivity to light quality. Plant, Cell \& Environment, 16(7), 851-858. https://doi.org/10.1111/j.1365-3040.1993.tb00507.x

Lv, S., Zhang, Y., Li, C., Liu, Z., Yang, N., Pan, L., ... Wang, G. (2018). Strigolactone-triggered stomatal closure requires hydrogen peroxide synthesis and nitric oxide production in an abscisic acid-independent manner. New Phytologist, 217(1), 290-304. https://doi.org/10.1111/ nph.14813

Ma, Y., \& Niu, J. (2017). The role of phytosphingosine-1-phosphate (Phyto$\mathrm{S} 1 \mathrm{P})$ and its relationships with cytosolic $\mathrm{pH}$ and hydrogen peroxide $\left(\mathrm{H}_{2} \mathrm{O}_{2}\right)$ during stomatal closure by darkness in broad bean. South African Journal of Botany, 108, 237-242. https://doi.org/10.1016/j. sajb.2016.11.002

Marron, N., Dreyer, E., Boudouresque, E., Delay, D., Petit, J. M., Delmotte, F. M., \& Brignolas, F. (2003). Impact of successive drought and rewatering cycles on growth and specific leaf area of two Populus $x$ canadensis (Moench) clones, 'Dorskamp' and 'Luisa_Avanzo'. Tree Physiology, 23(18), 1225-1235. https://doi.org/10.1093/treephys/ 23.18.1225

Maurel, C., Verdoucq, L., \& Rodrigues, O. (2016). Aquaporins and plant transpiration. Plant, Cell and Environment, 39(11), 2580-2587. https:// doi.org/10.1111/pce.12814

Merilo, E., Laanemets, K., Hu, H., Xue, S., Jakobson, L., Tulva, I., ... Kollist, H. (2013). PYR/RCAR receptors contribute to ozone, reduced air humidity, darkness, and $\mathrm{CO}_{2}$-induced stomatal regulation. Plant Physiology, 162(3), 1652-1668. https://doi.org/10.1104/pp.113.220608

Merilo, E., Yarmolinsky, D., Jalakas, P., Parik, H., Tulva, I., Rasulov, B., ... Kollist, H. (2018). Stomatal VPD response: There is more to the story than ABA. Plant Physiology, 176(1), 851-864. https://doi.org/ 10.1104/pp.17.00912

Mestdagh, P., Van Vlierberghe, P., De Weer, A., Muth, D., Westermann, F., Speleman, F., \& Vandesompele, J. (2009). A novel and universal method for microRNA RT-qPCR data normalization. Genome Biology, 10(6), 10.

Monclus, R., Dreyer, E., Villar, M., Delmotte, F. M., Delay, D., Petit, J. M., ... Brignolas, F. (2006). Impact of drought on productivity and water use efficiency in 29 genotypes of Populus deltoides $\times$ Populus nigra. New Phytologist, 169(4), 765-777. https://doi.org/10.1111/j.1469-8137. 2005.01630.x

Mott, K. A. (2007). Leaf hydraulic conductivity and stomatal responses to humidity in amphistomatous leaves. Plant, Cell and Environment, 30(11), 1444-1449. https://doi.org/10.1111/j.1365-3040.2007. 01720.x

Mott, K. A., Cardon, Z. G., \& Berry, J. A. (1993). Asymmetric patchy stomatal closure for the 2 surfaces of Xanthium strumarium leaves at low humidity. Plant, Cell and Environment, 16(1), 25-34. https://doi.org/ 10.1111/j.1365-3040.1993.tb00841.x

Muller, E., \& Lambs, L. (2009). Daily variations of water use with vapor pressure deficit in a plantation of 1214 poplars. Water, 1(1), 32-42. https://doi.org/10.3390/w1010032

Nourbakhsh-Rey, M., \& Libault, M. (2016). Decipher the molecular response of plant single cell types to environmental stresses. BioMed Research International, 2016, 1-8. https://doi.org/10.1155/2016/ 4182071

Novakova, M., Motyka, V., Dobrev, P. I., Malbeck, J., Gaudinova, A., \& Vankova, R. (2005). Diurnal variation of cytokinin, auxin and abscisic acid levels in tobacco leaves. Journal of Experimental Botany, 56(421), 2877-2883. https://doi.org/10.1093/jxb/eri282
Pallardy, S. G., \& Kozlowski, T. T. (1979). Stomatal response of populus clones to light intensity and vapor pressure deficit. Plant Physiology, 64(1), 112-114. https://doi.org/10.1104/pp.64.1.112

Park, S.-Y., Fung, P., Nishimura, N., Jensen, D. R., Fujii, H., Zhao, Y., ... Cutler, S. R. (2009). Abscisic acid inhibits PP2Cs via the PYR/PYL family of ABA-binding START proteins. Science (New York, N.Y.), 324(5930), 1068-1071.

Possen, B. J. H. M., Oksanen, E., Rousi, M., Ruhanen, H., Ahonen, V., Tervahauta, A., ... Vapaavuori, E. (2011). Adaptability of birch (Betula pendula Roth) and aspen (Populus tremula L.) genotypes to different soil moisture conditions. Forest Ecology and Management, 262(8), 1387-1399. https://doi.org/10.1016/j.foreco.2011.06.035

Pouchou, J.-L., \& Pichoir, F. (1991). Quantitative analysis of homogeneous or stratified microvolumes applying the model "PAP". In K. F. J. Heinrich, \& D. E. Newbury (Eds.), Electron Probe Quantitation (pp. 31-75). Boston, MA: Springer US.

Raschke, K., \& Schnabl, H. (1978). Availability of chloride affects balance between potassium-chloride and potassium malate in guard cells of Vicia faba L. Plant Physiology, 62(1), 84-87. https://doi.org/10.1104/ pp.62.1.84

Richardson, F., Brodribb, T. J., \& Jordan, G. J. (2017). Amphistomatic leaf surfaces independently regulate gas exchange in response to variations in evaporative demand. Tree Physiology, 37(7), 869-878. https://doi. org/10.1093/treephys/tpx073

Rodriguez-Dominguez, C. M., Buckley, T. N., Egea, G., de Cires, A., Hernandez-Santana, V., Martorell, S., \& Diaz-Espejo, A. (2016). Most stomatal closure in woody species under moderate drought can be explained by stomatal responses to leaf turgor. Plant, Cell and Environment, 39(9), 2014-2026. https://doi.org/10.1111/pce.12774

Santelia, D., \& Lawson, T. (2016). Rethinking guard cell metabolism. Plant Physiology, 172(3), 1371-1392.

Sato, A., Sato, Y., Fukao, Y., Fujiwara, M., Umezawa, T., Shinozaki, K., ... Uozumi, N. (2009). Threonine at position 306 of the KAT1 potassium channel is essential for channel activity and is a target site for ABAactivated SnRK2/OST1/SnRK2.6 protein kinase. Biochemical Journal, 424, 439-448. https://doi.org/10.1042/BJ20091221

Schroeder, J. I., \& Hagiwara, S. (1989). Cytosolic calcium regulates ion channels in the plasma membrane of Vicia faba guard cells. Nature, 338, 427-430. https://doi.org/10.1038/338427a0

Schroeder, J. I., \& Hedrich, R. (1989). Involvement of ion channels and active transport in osmoregulation and signaling of higher plant cells. Trends in Biochemical Sciences, 14(5), 187-192. https://doi.org/ 10.1016/0968-0004(89)90272-7

Schroeder, J. I., Raschke, K., \& Neher, E. (1987). Voltage dependence of K+ channels in guard-cell protoplasts. Proceedings of the National Academy of Sciences, 84(12), 4108-4112. https://doi.org/10.1073/pnas.84. 12.4108

Seung, D., Risopatron, J. P. M., Jones, B. J., \& Marc, J. (2012). Circadian clock-dependent gating in ABA signalling networks. Protoplasma, 249(3), 445-457. https://doi.org/10.1007/s00709-011-0304-3

Sheriff, D. W. (1979). Water-vapor and heat-transfer in leaves. Annals of Botany, 43(2), 157-171. https://doi.org/10.1093/oxfordjournals.aob. a085620

Shimazaki, K.-i., Doi, M., Assmann, S. M., \& Kinoshita, T. (2007). Light regulation of stomatal movement. Annual Review of Plant Biology, 58, 219-247.

Sommer, A., Geist, B., Da Ines, O., Gehwolf, R., Schäffner, A. R., \& Obermeyer, G. (2008). Ectopic expression of Arabidopsis thaliana plasma membrane intrinsic protein 2 aquaporins in lily pollen increases the plasma membrane water permeability of grain but not of tube 
protoplasts. New Phytologist, 180(4), 787-797. https://doi.org/ 10.1111/j.1469-8137.2008.02607.x

Sperry, J. S., Hacke, U. G., Oren, R., \& Comstock, J. P. (2002). Water deficits and hydraulic limits to leaf water supply. Plant, Cell and Environment, 25(2), 251-263. https://doi.org/10.1046/j.0016-8025. 2001.00799.x

Talbott, L. D., \& Zeiger, E. (1996). Central roles for potassium and sucrose in guard-cell osmoregulation. Plant Physiology, 111(4), 1051-1057. https://doi.org/10.1104/pp.111.4.1051

Tardieu, F., \& Simonneau, T. (1998). Variability among species of stomatal control under fluctuating soil water status and evaporative demand: Modelling isohydric and anisohydric behaviours. Journal of Experimental Botany, 49, 419-432. https://doi.org/10.1093/jxb/49.Special_ Issue.419

Touma, D., Ashfaq, M., Nayak, M. A., Kao, S.-C., \& Diffenbaugh, N. S. (2015). A multi-model and multi-index evaluation of drought characteristics in the 21st century. Journal of Hydrology, 526, 196-207. https:// doi.org/10.1016/j.jhydrol.2014.12.011

Tschaplinski, T. J., \& Blake, T. J. (1989). Water relations, photosynthetic capacity, and root shoot partitioning of photosynthates as determinants of productivity in hybrid poplar. Canadian Journal of BotanyRevue Canadienne De Botanique, 67(6), 1689-1697.

Tuskan, G. A., DiFazio, S., Jansson, S., Bohlmann, J., Grigoriev, I., Hellsten, U., ... Rokhsar, D. (2006). The genome of black cottonwood, Populus trichocarpa (Torr. and Gray). Science, 313(5793), 1596-1604. https:// doi.org/10.1126/science.1128691

Urban, J., Ingwers, M., McGuire, M. A., \& Teskey, R. O. (2017). Stomatal conductance increases with rising temperature. Plant Signaling \& Behavior, 12(8), 3.

Vandeleur, R. K., Mayo, G., Shelden, M. C., Gilliham, M., Kaiser, B. N., \& Tyerman, S. D. (2009). The role of plasma membrane intrinsic protein aquaporins in water transport through roots: diurnal and drought stress responses reveal different strategies between isohydric and anisohydric cultivars of grapevine. Plant Physiology, 149(1), 445-460. https://doi.org/10.1104/pp.108.128645

Vandesompele, J., De Preter, K., Pattyn, F., Poppe, B., Van Roy, N., De Paepe, A., \& Speleman, F. (2002). Accurate normalization of real-time quantitative RT-PCR data by geometric averaging of multiple internal control genes. Genome Biology, 3(7), research0034.1. https://doi.org/ 10.1186/gb-2002-3-7-research0034

Viger, M., Smith, H. K., Cohen, D., Dewoody, J., Trewin, H., Steenackers, M., ... Taylor, G. (2016). Adaptive mechanisms and genomic plasticity for drought tolerance identified in European black poplar (Populus nigra L.). Tree Physiology, 36(7), 909-928. https://doi.org/10.1093/treephys/ tpw017

Wang, X.-Q., Wu, W.-H., \& Assmann, S. M. (1998). Differential responses of abaxial and adaxial guard cells of broad bean to abscisic acid and calcium. Plant Physiology, 118(4), 1421-1429. https://doi.org/10.1104/ pp.118.4.1421

Wilkins, O., Waldron, L., Nahal, H., Provart, N. J., \& Campbell, M. M. (2009). Genotype and time of day shape the Populus drought response. Plant
Journal, 60(4), 703-715. https://doi.org/10.1111/j.1365-313X.2009. 03993.x

Yakir, E., Hassidim, M., Melamed-Book, N., Hilman, D., Kron, I., \& Green, R. M. (2011). Cell autonomous and cell-type specific circadian rhythms in Arabidopsis. Plant Journal, 68(3), 520-531. https://doi.org/10.1111/ j.1365-313X.2011.04707.x

Yoshida, R., Umezawa, T., Mizoguchi, T., Takahashi, S., Takahashi, F., \& Shinozaki, K. (2006). The regulatory domain of SRK2E/OST1/SnRK2.6 interacts with $A B I 1$ and integrates abscisic acid (ABA) and osmotic stress signals controlling stomatal closure in Arabidopsis. Journal of Biological Chemistry, 281(8), 5310-5318. https://doi.org/10.1074/jbc. M509820200

Zhang, X., Dong, F. C., Gao, J. F., \& Song, C. P. (2001). Hydrogen peroxideinduced changes in intracellular $\mathrm{pH}$ of guard cells precede stomatal closure. Cell Research, 11(1), 37-43. https://doi.org/10.1038/sj.cr.729 0064

Zhang, X. L., Jiang, L., Xin, Q., Liu, Y., Tan, J. X., \& Chen, Z. Z. (2015). Structural basis and functions of abscisic acid receptors PYLs. Frontiers in Plant Science, 6. https://doi.org/10.3389/fpls.2015.00088

\section{SUPPORTING INFORMATION}

Additional supporting information may be found online in the Supporting Information section at the end of the article.

Table S1 List of gene studied with their specific primers.

Table S2 Dataset used for statistical analysis (see separate Excel file).

Table S3 Summary of the genotype, water treatment, time of day and leaf side partial $\mathrm{R}^{2}$ of stomatal conductance, guard cell element content and expression of genes of interest.

Figure S1 Guard cell element content of four poplar genotypes under contrasting water availability with each leaf side measured separately once in the morning and once in the afternoon (10:30 and 15:00).

Figure S2 Normalized guard cell transcript accumulation of four poplar genotypes under contrasting water availability with each leaf side measured separately once in the morning and once in the afternoon (10:30 and 15:00).

Data S2: Supplementary Information

How to cite this article: Durand M, Cohen D, Aubry N, et al. Element content and expression of genes of interest in guard cells are connected to spatiotemporal variations in stomatal conductance. Plant Cell Environ. 2019;1-16. https://doi.org/ 10.1111/pce.13644 